\title{
Mercury Speciation Modeling Using Site Specific Chemical and Redox Data from the TNXOD OU
}

by

D. I. Kaplan

Westinghouse Savanniah River Company

Savannah River Site

Aiken, South Carolina 29808

J. Myers

Clemson University

SC USA
A. C. Knox

SREL, University of Georgia

SC USA

G. Iverson

WSRC

S. Serkiz

WSRC

This paper was prepared in connection with work done under the above contract number with the U.S.

Department of Energy. By acceptance of this paper, the publisher and/or recipient acknowledges the $U$. S.

Government's right to retain a nonexclusive, royalty-free license in and to any copyright covering this paper, along with the right to reproduce and to authorize others to reproduce all or part of the copyrighted paper. 


\section{DISCLAIMER}

This report was prepared as an account of work sponsored by an agency of the United States Government. Neither the United States Government nor any agency thereof, nor any of their employees, makes any warranty, express or implied, or assumes any legal liability or responsibility for the accuracy, completeness, or usefulness of any information, apparatus, product or process disclosed, or represents that its use would not infringe privately owned rights. Reference herein to any specific commercial product, process or service by trade name, trademark, manufacturer, or otherwise does not necessarily constitute or imply its endorsement, recommendation, or favoring by the United States Government or any agency thereof. The views and opinions of authors expressed herein do not necessarily state or reflect those of the United States Government or any agency thereof.

This report has been reproduced directly from the best available copy.

Available for sale to the public, in paper, from: U.S. Department of Commerce, National Technical Information Service, 5285 Port Royal Road, Springfield, VA 22161, phone: (800) 553-6847, fax: (703) 605-6900

email: orders@ntis.fedworld.gov

online ordering: http://www.ntis.gov/ordering,htm

Available electronically at http://www.doe.gov/bridge

Available for a processing fee to U.S. Department of Energy and its contractors, in paper, from: U.S. Department of Energy, Office of Scientific and Technical Information, P.0. Box 62,

Oak Ridge, TN 37831-0062,

phone: (865)576-8401,

fax: (865)576-5728

email: reportsladonis.osti.gov 


\section{DISCLAIMER}

Portions of this document may be illegible in electronic image products. Images are produced from the best available original document. 
Keywords: Chemical speciation, Redox, TNX, Wetlands

Retention: Permanent

\section{Mercury Speciation Modeling Using Site Specific Chemical and Redox Data from the TNXOD OU (U)}

\footnotetext{
Daniel Kaplan $^{(1)}$, James Myers ${ }^{(2)}$, Anna Knox ${ }^{(3)}$, Gary Iversen ${ }^{(1)}$, Steven Serkiz ${ }^{(1)}$
}

(1) Savannah River Technology Center, Westinghouse Savannah River Company, Aiken, SC 29808

(2) Environmental Engineering \& Science, Clemson University, Clemson, South Carolina 29634-0919

(3) Savannah River Ecology Laboratory, University of Georga, Aiken, SC 29808

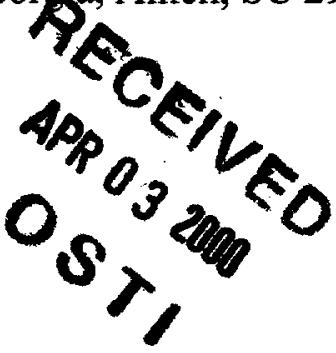

Westinghouse Savannah River Company

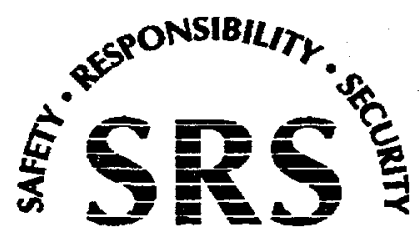




\title{
WSRC-TR-2000-00058
}

Keywords: Chemical speciation, Redox, TNX, Wetlands

Retention: Permanent

\section{Mercury Speciation Modeling Using Site Specific Chemical and Redox} Data from the TNXOD OU (U)

\author{
March 6, 2000
}
Daniel Kaplan $^{(1)}$, James Myers ${ }^{(2)}$, Anna Knox ${ }^{(3)}$, Gary Iversen ${ }^{(1)}$, Steven Serkiz ${ }^{(1)}$

(1) Savannah River Technology Center, Westinghouse Savannah River Company, Aiken, SC 29808

(2) Environmental Engineering \& Science, Clemson University, Clemson, South Carolina 29634-0919

(3) Savannah River Ecology Laboratory, University of Georgia, Aiken, SC 29808
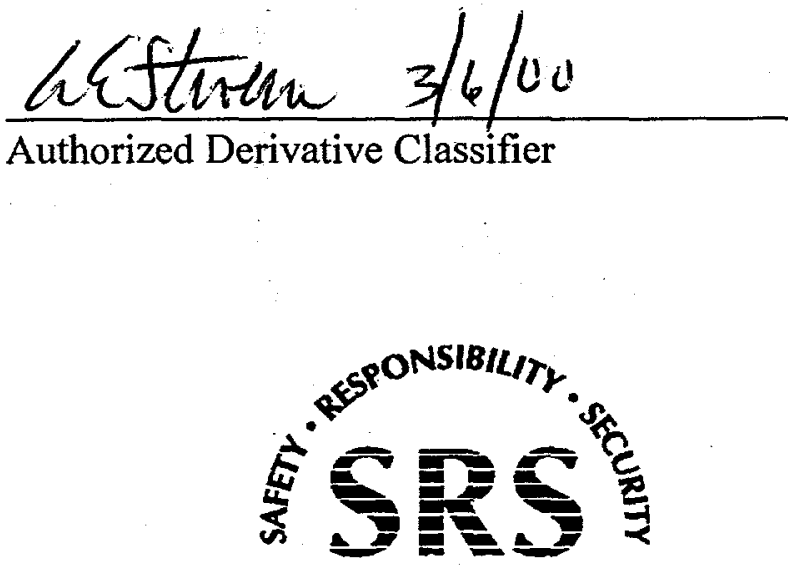
WSRC-TR-2000-00058

Authors
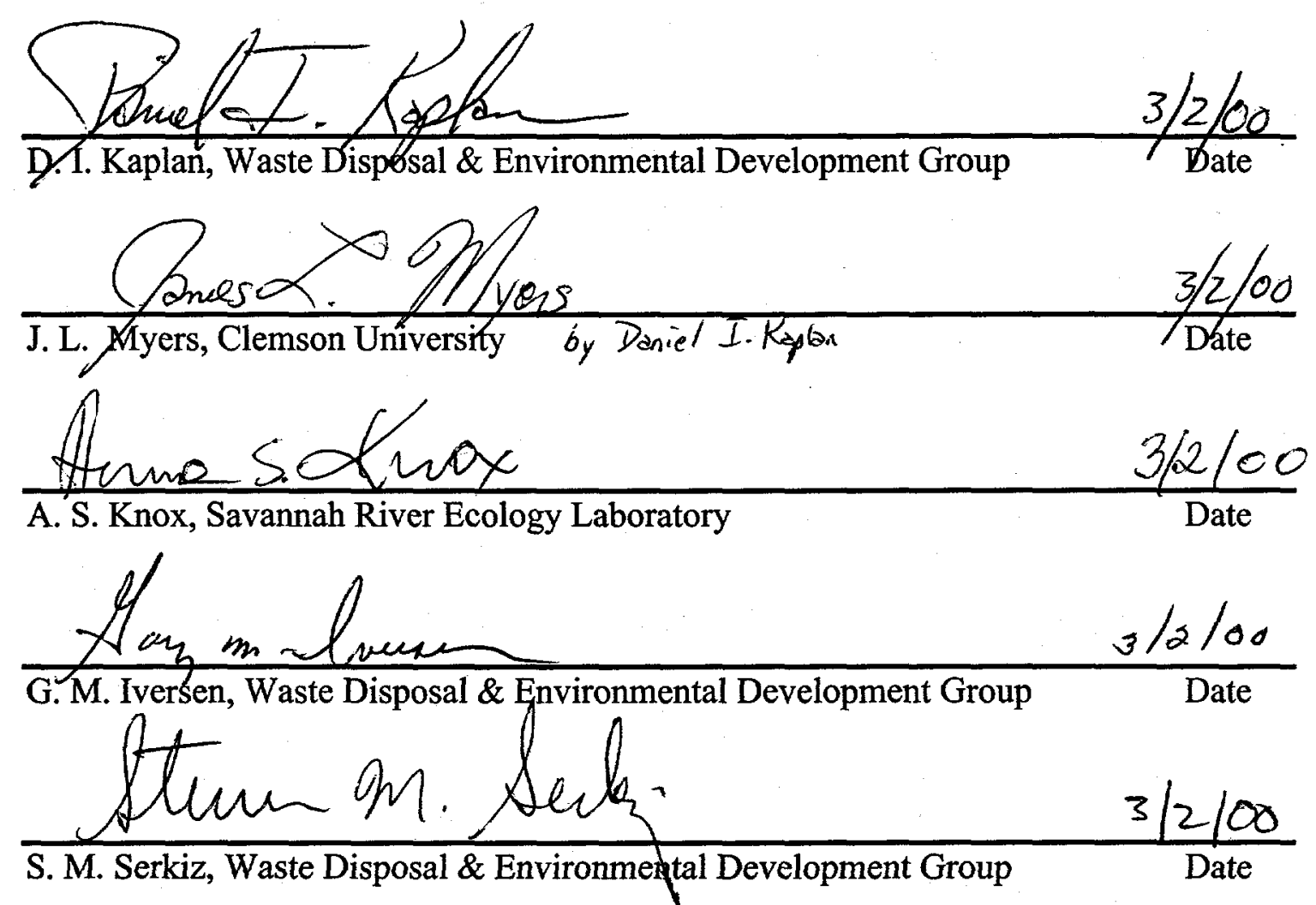

2 


\section{Design Check}

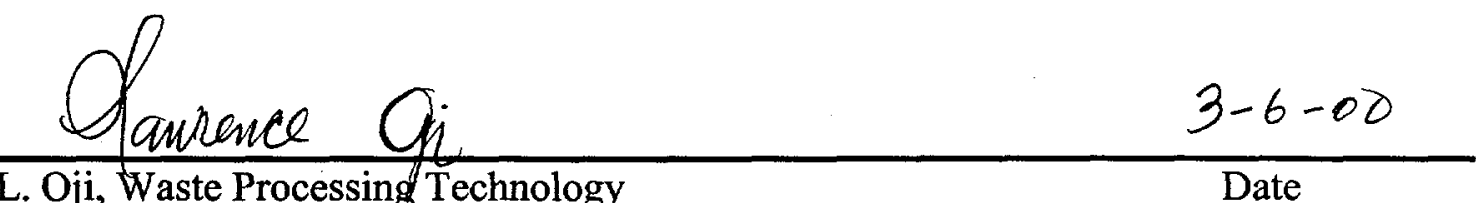

L. Oji, Waste Processing Technology

Date

(per Manual E7, Procedure 2.40)

Approval

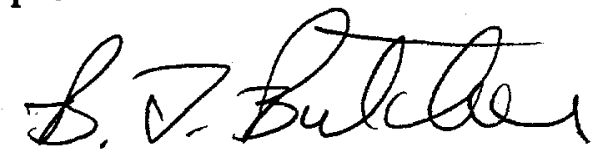

$3-3-00$

B. T. Butcher, Level 4 Manager

Date

Waste Disposal \& Environmental Development Group 


\section{Executive Summary}

Previous research related to the TNX Outfall Delta Operable Unit indicated that the mercury in the contaminated sediment was strongly sorbed to the sediment (Kaplan and Serkiz 2000) and it was not toxic (Specht 1999). These two sets of studies were conducted under oxygenated or mildly reducing conditions. The objective of this study was to evaluate mercury speciation under reducing conditions expected in sediments at the TNX Outfall Delta. These changes in speciation would then be used to infer whether mercury toxicity and mobility would be expected (or predicted?) to be significantly altered under reducing conditions.

Because the cost of conducting desorption and toxicity tests under reducing conditions would be expensive and time consuming, it was decided to attempt to evaluate this issue through the use of thermodynamic speciation calculations based on site-specific data. Four sets of calculations were conducted (each set comprising 33 individual calculations), whereby the dominant mercury species were estimated thermodynamically as a function of the oxidation-reduction potential (ORP or Eh values). Attempts were made to relate the results to experimental results reported in the literature. Additionally, 58 field measurements of Eh were made in sediments at or adjacent to the TNX Outfall Delta waste site. Because no Eh measurements had been made at the study site, the measured Eh values provided an indication of the range of likely values that may exist at the study site. There is some uncertainty in the application of these measurements to site processes due to the fact that they did not capture the anticipated seasonal variation of Eh values.

The measured Eh values varied a great deal, likely the result of differences in the microenvironment of the sample. The Eh values were in the range of expected values for acidic environments $(\mathrm{pH} \sim 5)$. The speciation calculation indicated that as the redox potential decreased, the availability of mercury tended to decrease presumably due to the formation of $\mathrm{HgS}$, a sparingly soluble precipitate. No abiotic methylated mercury was predicted to be formed within the range of likely redox levels for this mildly acidic site. This is an important finding because methylated mercury species are highly toxic. As the $\mathrm{pH}$ of the system was increased, less mercury was predicted to precipitate, thereby leaving more in the mobile aqueous phase.

One potential concern with the calculations is that they do not include the influence of microbial activity. It is well documented that microbes can greatly influence mercury speciation by directly altering its oxidation state and by promoting the formation of methylated species. Without direct experimentation to address this question, it is difficult to predict the impact microbes would have on the calculated speciation results. However, these calculations suggest that less soluble mercury would be expected to exist under reducing conditions. Microbes have been shown to methylate dissolved, weakly sorbed (perhaps exchangeable) and a small fraction of organic-bound mercury (Beijer and 
Jernelov 1979). Abiotic (non-biological) methylation processes are highly correlated to only the dissolved mercury species. Sequential extraction data reported by Kaplan and Serkiz (2000) indicated that 0 to $8 \%$ of the total mercury in five contaminated TNX sediments were in the aqueous, weakly sorbed, or organic fractions. Essentially all the mercury was strongly held to the solid phase, likely as $\mathrm{HgS}$ or as part of the structure of crystalline Fe-oxides. These results suggest that once the system becomes reduced, little mercury would remain in an available form for the microbes to methylate.

In conclusion, the results from this work suggest that mercury would likely become more strongly retained by the solid phase under reducing conditions than under oxidizing conditions at the TNX Outfall Delta site. Considering that experimental results indicate that mercury is extremely tightly bound to the solid phase under oxidizing conditions, little mercury mobility would therefore be expected under reducing conditions.

Additionally, these calculations suggest that little additional methylated mercury should be expected when the system becomes reduced. The mildly acid conditions of the site are a natural deterrent to the formation of mobile and toxic mercury species under reducing conditions due to the formation of $\mathrm{HgS}$. 


\section{Table of Contents}

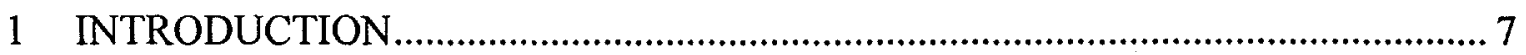

1.1 Mercury Contamination at the TNX Outfall Delta Operable Unit ....................... 7

1.2 Overview of Mercury Aqueous Chemistry ....................................................... 7

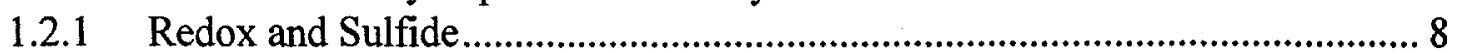

1.2.2 Organic Matter-Mercury and Methylmercury Species.................................. 8

1.3 Over view of Mercury Sorption to Sediments ............................................... 10

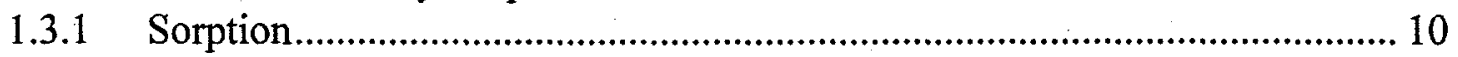

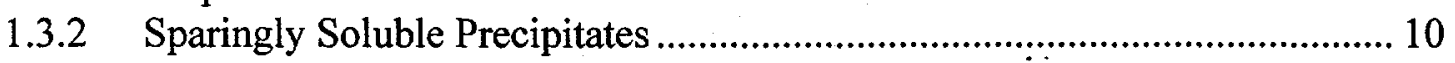

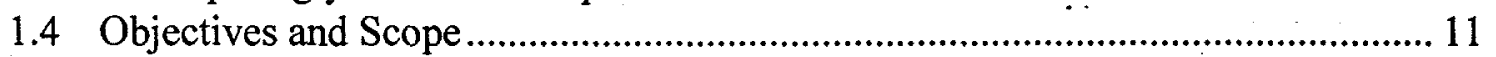

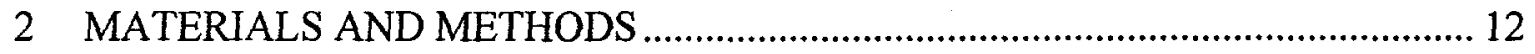

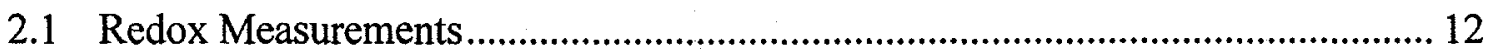

2.2 Mercury Speciation Calculations ................................................................. 15

2.3 Sample Analysis and Quality Assurance .................................................... 17

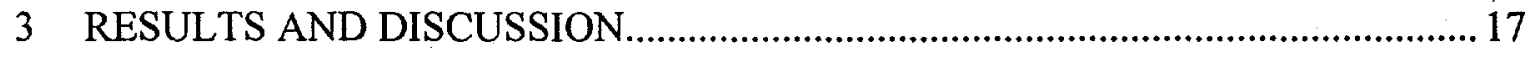

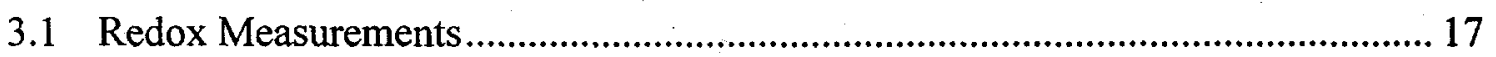

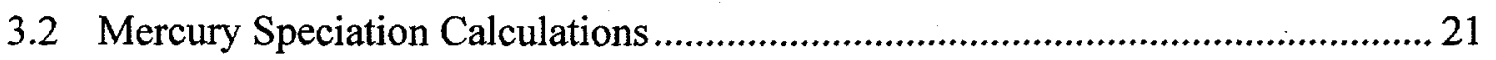

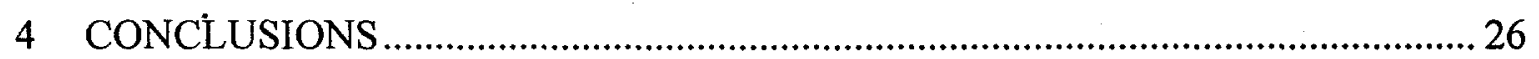

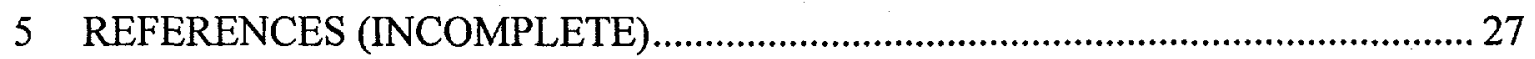

APPENDIX: THERMODYNAMIC SPECIATION RESULTS: DATA USED IN

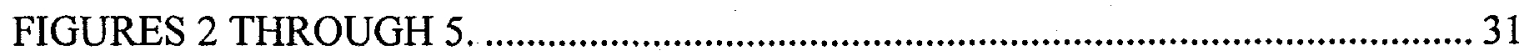




\section{Introduction}

\subsection{Mercury Contamination at the TNX Outfall Delta Operable Unit}

The TNX pilot-scale research facility located on the Savannah River Site, released process waste into an unlined seepage basin between 1958 and 1980. The basin, referred to as the Old TNX Seepage Basin, was designed to contain wastewater until it could seep into the underlying sediments, which in tern would act as an ion exchange media. The waste discharged to the Old TNX Seepage Basin included large quantities of mercury, sodium compounds, depleted uranium, thorium, and other radionuclides and heavy metals. The basin contents are believed to have entered the nearby wetland area, the TNX Outfall Delta Operable Unit, by subsurface flow and overland flow (a result of purposely breaching a basin wall and routinely overfilling the basins).

The mercury that was introduced into the basins was primarily in the form of mercuric nitrate $\left[\mathrm{Hg}\left(\mathrm{NO}_{3}\right)_{2}-x \mathrm{H}_{2} \mathrm{O}\right]$ (WSRC 1999a). Total mercury concentrations in the sediments in the TNX Outfall Delta are as great as $30.8 \mathrm{mg} / \mathrm{kg}$ (WSRC 1999b). These mercury levels are appreciably greater than unit specific background levels: the average background soil concentration is $0.0535 \mathrm{mg} / \mathrm{kg}$ and the average background sediment concentration is $0.0505 \mathrm{mg} / \mathrm{kg}$ (WSRC 1999b). Laboratory studies were conducted in part to understand the geochemistry of mercury in the Outfall Delta Operable Unit (Kaplan and Serkiz 2000). Sequential extraction data from five contaminated sediments collected from the operable unit revealed that the mercury was very strongly sorbed to the sediment. Between 92 and $100 \%$ of the total mercury present in these five sediment samples was very strongly associated with the solid phase (i.e., the mercury was associated with the crystalline Fe-oxides or the mineral structure fractions). The remaining 0 to $8 \%$ of the mercury in these sediments was associated with more mobile or bioavailable fractions (i.e., the mercury was associated with the dilute-acid extractable, organic, or amorphous $\mathrm{Fe}$-oxide fraction).

Recently, toxicity tests were conducted using Chironomus tentans and Hyalella azteca on sediments collected from the TNX Outfall Delta Operable Unit (Specht 1999). Sediment and soil samples that contained very high total mercury and uranium concentrations were no more toxic than the background reference samples. This suggested to the researcher that the contaminated soils and sediments in this operable unit are not acutely toxic to aquatic biota.

\subsection{Overview of Mercury Aqueous Chemistry}

The environmental factors in the TNX Outfall Delta Operable Unit that may have the greatest impact on chemical speciation are redox potential and $\mathrm{pH}$, and chloride, organic matter, and sulfur concentrations. 


\subsubsection{Redox and Sulfide}

Depending on the redox condition of a sediment, mercury may occur in three oxidation states, $\mathrm{Hg}(0), \mathrm{Hg}(\mathrm{I})$, and $\mathrm{Hg}(\mathrm{II})$. The $\mathrm{Hg}(0)$ and $\mathrm{Hg}(\mathrm{II})$ are the most common states in nature (Lindsay 1971, Andersson 1979). In well-aerated, oxygen-containing waters (Eh $\sim 500 \mathrm{mV}), \mathrm{Hg}(\mathrm{II})$ species will be the predominant form of inorganic soluble mercury. Metallic mercury, $\operatorname{Hg}(0)$, should prevail under mildly oxidizing or reducing conditions, unless enough sulfide is present to stabilize sulfide complexes or bivalent mercury. Under strongly reducing conditions, $\mathrm{Hg}(\mathrm{II})$ converts to $\mathrm{Hg}(0)$. At somewhat greater redox potential conditions, meta-cinnabar $(\mathrm{HgS})$ will precipitate. More oxidizing redox conditions will bring about the oxidation of sulfide to sulfate, but at this point the potential is still not high enough to convert $\mathrm{Hg}(0)$ to $\mathrm{Hg}(\mathrm{II})$. Stated differently, sulfide has a lower standard reduction potential than $\mathrm{Hg}(0)$. Further rise in redox potential to levels commonly found in surface soils will transform mercury into the +2 oxidation state. Hepler and Olofsson (1975) and Andersson (1979) give a more detailed treatment of the physical chemistry of mercury in aqueous solutions.

The solubility of metallic mercury $\left(\mathrm{Hg}^{0}\right)$ in oxygen-free water is $\sim 1 \mathrm{E}-7 \mathrm{M}$ (Hem 1970). Even if liquid mercury were formed in some types of water it would probably soon be eliminated from the water body, either due to rapid sedimentation of dense droplets or as a result of volatilization. Consequently, in a pure form, this species cannot contribute significantly to the suspended and mobile forms of mercury. It can only be assumed that minute amounts of metallic mercury might be stabilized in the suspended phase by associating with the surface of suspended solids.

\subsubsection{Organic Matter-Mercury and Methylmercury Species}

Model experiments have shown that humic substances can strongly bind mercury (Wallschlager et al. 1998a; 1998b). Reimiers et al. (1974) reported enhanced solubility of $\mathrm{HgS}$ and mercuric oxide (HgO) in the presence of humic acids. The solubility increased with increasing $\mathrm{pH}$ from 5 to 7 . The probable ratio of the organic ligand to mercury in the complex was 2:1, the approximate formation constant was calculated to be $1.75 \times 10^{5}$. The mechanism of mercury binding by humic substances remains rather unclear. The high selectivity of humic substances for mercury might point to a possible reaction of mercury with sulfhydryl (HS-) groups in the organic matter. Other mechanisms usually considered to be responsible for metal-humic substances interactions are chelate formation and ion exchange (Gjessing 1976).

According to Alberts et al. (1974) mercuric ions $\left(\mathrm{Hg}^{2+}\right)$ can be reduced in aqueous solutions by humic acids, probably due to interaction with the free radical electrons of the humic acid. The reduction proceeds via first order kinetics (rate constant, $0.009 \mathrm{~h}^{-1}$ ) and is $\mathrm{pH}$-dependent. The $\mathrm{pH}$ influences the total amount of mercury reduced more than it 
influences the reduction rate. Microorganisms can also reduce mercuric ions to metallic mercury, resulting in greater likelihood of volatilization (Furukawa et al. 1969, Baier et al. 1975).

Methylated mercury compounds are the most toxic forms of mercury. These compounds can be divided into two broad types: 1) those in which the mercury atom are linked to one organic radical and 2) those in which the mercury are attached to two organic radicals. The first type is rather soluble in water and can dissociate to form cations $\left(\mathrm{R}-\mathrm{Hg}^{+}\right)$or anions $\left(\mathrm{X}^{-}\right)$. Its composition, its properties, and the extent of dissociation depend on the nature of the organic group bound to the mercury atom and on the composition of the aqueous solutions. Reimers and Krundel (1974) reported that methylmercuric chloride or hydroxide should predominate in natural water, depending on the $\mathrm{pH}$ and chloride concentration in the water. Zepp et al. (1974), found that methylated mercury was almost completely complexed with sulfides in fresh waters.

The second type of organic mercury complex includes compounds such as dimethylmercury and diphenylmercury. Because these compounds contain covalent bonds, they are volatile, nonpolar, and very hydrophobic (very poorly soluble in water). It can be assumed that dimethylmercury leaves water with bubbles or natural gases when it is formed in an aquatic system. Thus, it is rather improbable that dimethylmercury would represent a significant part of the mercury dissolved in water. Methyl- and dimethylmercury have been detected in soil gases (Andersson 1979).

Jernelov (1972) concluded that a higher rate of methylation occurs under anaerobic than in aerobic systems. However, if $\mathrm{H}_{2} \mathrm{~S}$ formed, which typically occurs in natural systems under strongly anaerobic conditions, $\mathrm{HgS}$ will precipitate and stop the methylation process. In an acidic environment, conditions favor organisms producing monomethylated mercury species (Jernelov 1972). In more alkaline environment, dimethylmercury is formed (Jernelov 1972). Since methylation promotes mercury volatilization, this process tends to reduce the total mercury concentration in sediments, particularly if dimethylmercury is the final specie. The methylated fraction usually accounts for $<1 \%$ of the total amount in soils (Van Faassen 1976).

Abiotic methylation seems to require dissolved species of inorganic or organic mercury (Beijer and Jernelov 1979). Biotic methylation can also utilize dissolved species, as well as mercury associated with organic matter (Beijer and Jernelov 1979). Because the fractions dissolved in the soil solution under normal conditions are negligible, the quantity methylated by the abiotic processes will likewise be small. Thus, the microbial processes are probably the most important in regards to the methylation process. However, it is important to note that the most intense volatilization does not occur when conditions are optimal for microbial activity. Instead, most volatilization occurs when conditions are conducive to the formation of the highly volatile dimethylmercury species, i.e., in neutral or alkaline soils. 


\subsection{Over view of Mercury Sorption to Sediments and Precipitation}

In general, only a small fraction of the total mercury in sediments exists in the interstitial waters and the remainder is sorbed to the sediment surfaces. The extent to which mercury is sorbed by sediments is controlled by a number of factors, including the chemical form of mercury, the grain size distribution of the sediment, sediment mineralogy, humic substance concentrations, soil $\mathrm{pH}$, and the redox potential. Steinnes (1990) concluded that the adsorption process dominated mercury removal from the aqueous phase under oxidized environments, and the precipitation process dominated mercury removal under reducing environments (as sulfides and selenides).

\subsubsection{Sorption}

It has been well documented that the chemical form of mercury is of primary importance in its sorption (reviewed by Benes and Havlik 1979). For instance, the hydrolyzed forms of mercury are generally sorbed more than the chloride complexes and that increasing hydrophobicity of an inorganic mercury species increases its potential to sorb; thus, $\mathrm{HgCl}_{2}(\mathrm{aq})$ sorbs less than $\mathrm{Hg}(\mathrm{OH})_{2}(\mathrm{aq})$, which in turn, sorbs less than $\mathrm{HgS}(\mathrm{aq})$ Reimers et al. (1974) reported that methylated mercury sorbed less than inorganic mercury on sand, montmorillonite, illite and various organic absorbents (Lockwood and Chen 1973; Benes and Havlik 1979). Newton et al. (1976), reported that $\mathrm{HgOHCl}^{0}$, a specie that occurs in neutral systems containing moderate concentrations of $\mathrm{Cl}$, is the dominating species in systems where maximum sorption occurs. It is not clear from this titration study, whether the presence of $\mathrm{HgOHCl}^{0}$ or the concomitant changes in the reactive surface sites were responsible for the enhanced mercury removal from the aqueous phase.

In oxidized SRS sediments, mercury sorption is likely to be dominated less by ion exchange, and more by surface complexation onto Fe-oxides, Al-oxides, and humic substances. Andersson (1979) reported the following sequence for the retention of inorganic $\mathrm{Hg}(\mathrm{II})$ under oxidizing, $\mathrm{pH} 7$ conditions: $\mathrm{Al}(\mathrm{OH})_{3}<$ kaolinite $<$ montmorillonite $<$ illite $<$ organic soils $<\mathrm{Fe}_{2} \mathrm{O}_{3}-x n \mathrm{H}_{2} \mathrm{O}$. Of these minerals, only the following minerals are found to any appreciable extent on the SRS: $\mathrm{Al}(\mathrm{OH})_{3}$ (gibbsite), kaolinite, organic soils, and $\mathrm{Fe}_{2} \mathrm{O}_{3}-x n \mathrm{H}_{2} \mathrm{O}$ (generically referred to as $\mathrm{Fe}$-oxides). The retention of mercury in an organic soil was not significantly reduced until $\mathrm{pH}<4$ (Steinnes 1990). In sediments with a $\mathrm{pH}>5.5$, Fe-oxides and clay minerals sorbed mercury more effectively. Maximum sorption generally occurred around $\mathrm{pH} 7$, where $\mathrm{HgOHCl}^{0}$ was the dominant species (Andersson 1979).

\subsubsection{Sparingly Soluble Precipitates}

Mercury forms a number of substances that are sparingly soluble in water. Hem (1970) calculated the stability of many of these compounds and concluded that no insoluble organic form of mercury is thermodynamically stable under conditions typical 
for aquatic systems. Of the inorganic compounds he evaluated, $\mathrm{HgCl}_{2}, \mathrm{Hg}_{2} \mathrm{Cl}_{2}, \mathrm{HgO}, \mathrm{Hg}^{0}$, and $\mathrm{HgS}$, only liquid elemental mercury $\left(\mathrm{Hg}^{\circ}\right)$ and solid mercuric sulfide $(\mathrm{HgS})$ species can be stable phases in natural water. The other inorganic compounds must be excluded in view of their rather high solubility, exceeding the very low concentrations of total mercury in natural waters (including those in the TNX Outfall Delta Operable Unit; WSRC 1999a).

\subsection{Objectives and Scope}

Kaplan and Serkiz (2000) reported that although the TNX Outfall Delta Operable Unit had high concentrations of total mercury in the sediment, little of that mercury was in a form that could be easily extracted. They also showed that uncontaminated sediments collected from near the Operative Unit sorbed large amounts of $\mathrm{Hg}^{2+}$; distribution coefficients (Kd values) were between 4700 and $5700 \mathrm{~mL} / \mathrm{g}$. These large $\mathrm{Kd}$ values are consistent with other mercury-Kd values measured in subsurface SRS sediments, where Kd values ranged between 956 to $8517 \mathrm{~mL} / \mathrm{g}$ (Kaplan and Iversen 1999). Additionally, Specht (1999) reported that contaminated sediments collected from this operative unit were no more toxic than the background reference samples. Together, these findings suggest that the mercury in these sediments is strongly sorbed to the sediments and is not in a toxic form.

An issue that remains for the risk analysis of the site is whether seasonal changes in the redox potential at the site influences mercury availability and toxicity. Specifically, wetland flooding varies greatly with the seasons and the flooding is expected to greatly influence the redox potential of these sediments (during flooded periods, the sediments would be more reduced). As discussed in the Introduction (Sections 1.1-1.3), redox potential has a significant effect on mercury speciation, and therefore on mercury mobility and toxicity. The toxicity (Specht 1999) and the geochemical (Kaplan and Serkiz 2000) studies were conducted under oxidizing or mildly reducing conditions, the condition of the "as received" sediment samples. The influence of low redox conditions associated with flooding on mercury speciation is not known.

The objectives of this study were:

(1) to collect site-specific field measurements of the redox potential at the TNX Outfall Delta Operable Unit, and

(2) to conduct thermodynamic mercury speciation calculations using site-specific aqueous and redox data.

Because this project had to be completed in about a month, we had a limited duration to collected redox measurements and therefore seasonal variations in the redox potential could not be evaluated. Consequently, sample locations were selected with the intent of measuring the redox potential at the site over the widest range of site geochemical conditions. To obtain a wide range of geochemical conditions, site locations expected to 
have high and low redox values were selected for sampling. It was expected that submerged locations with a low topography and a high organic matter sediment would have a low redox potential, and locations that were not submerged, were elevated, and had low organic matter concentrations were expected to have a high redox status. The measured redox range provided a site-specific information for basing subsequent chemical speciation calculations.

The overall objectives of the chemical speciation calculations were:

(1) to evaluate whether the strong mercury retention reported by Kaplan and Serkiz (2000) under oxidized or mildly reducing conditions could be attributed to precipitation,

(2) to evaluate whether the lack of toxicity noted by Specht (1999) under oxidized or mildly reducing conditions could be attributed to lack of toxic dissolved species (methylated mercury), and

(3) to quantitatively compare the species calculated to exist under reducing conditions to those under oxidizing conditions in terms of this toxicity and sorption potential.

Regarding this last objective, because the sorption potential and toxicity of mercury under oxidized systems have been evaluated, comparisons between the calculated reducing and oxidizing species would be valuable.

\section{Materials and Methods}

\subsection{Redox Measurements}

The oxidation-reduction potential (ORP), or Eh, measurements, were conducted using the standard platinum-electrode method (Patrick et al. 1996). A Pt/Ag-AgCl probe (Cole Palmer Ref N99-8978, Vernon Hills, IL) was used with an Eh/pH portable meter (Orion, 250A; Boston, MA).

It is important to note that the intent of this sampling was not to provide a statistical description of the Eh levels at the site. Instead the sampling was designed to provide the greatest range of Eh levels. $\mathrm{pH}$ was measured along with Eh because the two parameters are very closely related and the $\mathrm{pH}$ parameter is useful in interpreting Eh values for geochemical significance (Baas-Becking et al. 1960, Lindsay 1971, Sposito 1994). 


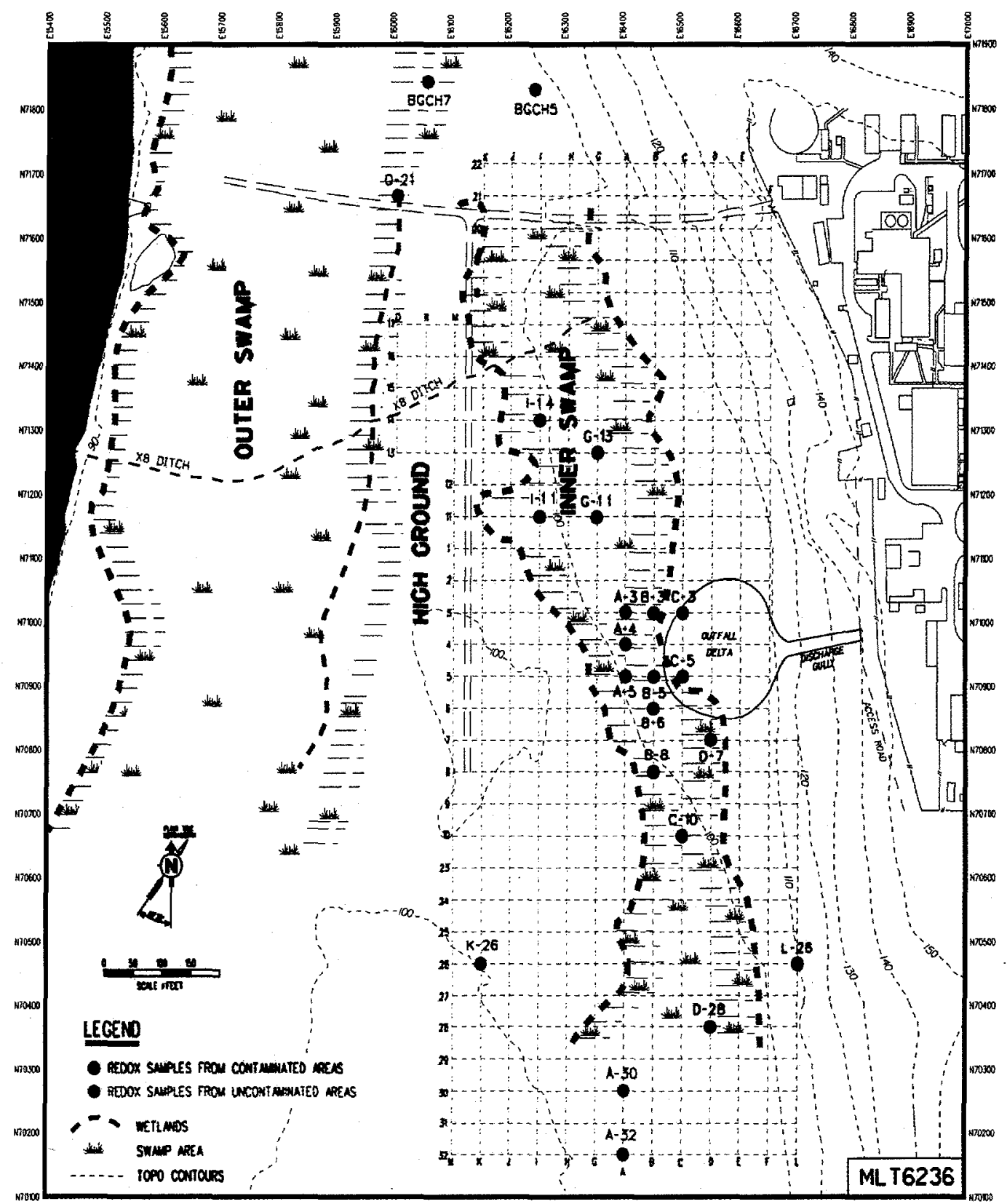

Figuro 1. Samplo Locatione for Rodex Moenuromenta from the TNX Outfall Dolta Operablo Unit 
A total of 58 measurements were taken from 23 locations (Figure 1). At two of the locations, $0-21$ and BGCH-5, redox and $\mathrm{pH}$ measurements were taken as a function of depth. Duplicate or triplicate measurements of specific samples were made.

Measurements in an adjacent uncontaminated area near the operable unit were conducted on January 12, 2000 (A-31, A-32, BGCH-5, BGCH-7, K-26, and O-21). Measurements in the operable unit were conducted on January 29,2000 . During these two sampling days, the study site was relatively dry and only a few locations were submerged. The nearby Savannah River had been unusually low during and prior to sampling, reducing the extent of flooding at the site. The flooding history of the site is important because it directly affects the Eh of the sediments. The relatively dry site created an overall more oxidizing environment, an environment with a greater Eh level.

Sediment samples were collected by scraping away the litter layer from the ground and scooping 20-cc of the surface mineral sediment into a disposable plastic cup. To this sediment, 20-cc of distilled-deionized water was added. The suspension was stirred and allowed to equilibrate for 30 minutes. Eh, temperature, and $\mathrm{pH}$ readings were taken of the slurry. Temperature readings were necessary to convert the Eh values to a $25^{\circ} \mathrm{C}$ basis. Between samples, the sampling spatula, thermometer and electrodes were rinsed with DI water and dried with paper towels.

$\mathrm{pH}$ measurements were calibrated with $\mathrm{pH} 4$ and 7 buffer after every 10 measurements using standard methods (Thomas 1996). There is no calibration of the Eh measurement. Instead there is a test to determine whether the electrode and meter are working properly. If the electrode/meter combination is outside of the specifications of the test, then one or both components needs to be replaced. Briefly, the test involves dissolving $0.2 \mathrm{~g}$ of quinhydrone into $100 \mathrm{~mL}$ of $\mathrm{pH}-7$ and $\mathrm{pH}-4$ buffer solutions. For the $\mathrm{pH}-7.0$ /quinhydrone solution, the meter should read between +70 and $+110 \mathrm{mV}$; on average, 84-mV was measured. For the $\mathrm{pH}-4$ /quinhydrone solution, the meter should read between +240 and $+280 \mathrm{mV}$; on average, $259-\mathrm{mV}$ was measured. This test verified the function of the platinum combination redox electrode by actual measurement of the known oxidation-reduction potential change. An additional test to determine whether the reference junction is plugged or the electrode internal solution is contaminated, requires that the difference in the millivolt readings for the two test solutions should be between $\Delta 169$ and $\Delta 177 \mathrm{mV}$. In our case $\Delta=259-84=175 \mathrm{mV}$, indicating the instrument was operating correctly.

In addition to making the $\mathrm{pH}$ and $\mathrm{Eh}$ measurements, a brief description of the sediments was noted. It was anticipated that these descriptions would be useful in relating soil properties to measured Eh values. The following terms were used for soil descriptions:

- Clean sand - no evidence of organics or iron oxyhydroxides,

- Orange sand - sand grains were coated with iron oxyhydroxides,

- Brown sand or clay - some organics were mixed in with sand or clay,

- Gley - a greenish to gray colored sand or clay indicating a reducing environment, 
- Organic mat - forest litter $1 / 2$ " to 3" thick,

- Sandy clay - predominantly clay but some quartz grit,

- Clayey sand - predominantly sand but enough clay present for soil to be plastic.

\subsection{Mercury Speciation Calculations}

The U.S. EPA's geochemical speciation model MINTEQA2 Version 3.11 (Allison et al. 1991) was used to calculate the equilibrium concentrations of dissolved and solid species for this system. MINTEQA2 has a database of almost 1500 possible species. Turner et al. (1993), modified the version 3.11 database by adding thermodynamic data for activation products, fission products, and actinides. The Turner version of the database was used for this work.

Thermodynamic data for nine methyl mercury species (Stumm and Morgan, 1981) and one mercury-dissolved organic matter (Hg-DOM) complex (Cheam and Gamble, 1974) were added to the database to ensure that appropriate mercury species were included in the calculations. These species along with their logarithm equilibrium constants (Log $\mathrm{K}$ values) are listed in Table 1. In addition to these 10 species, the equilibrium constants for 32 other mercury species are included in the MINTEQA2 model.

Table 1. Equilibrium constants (Log K) added to the MINTEQA2 thermodynamic database.

\begin{tabular}{|c|c|}
\hline Species & $\log \mathrm{K}$ \\
\hline $\mathrm{Hg}(\mathrm{OH})_{2}+\mathrm{CO}_{3}{ }^{2-}+8 \mathrm{e}^{-}+11 \mathrm{H}^{+}=\mathbf{H g C H}_{3}^{+}+5 \mathrm{H}_{2} \mathrm{O}$ & 50.2 \\
\hline $\mathrm{Hg}(\mathrm{OH})_{2}+2 \mathrm{CO}_{3}{ }^{2-}+16 \mathrm{e}^{-}+20 \mathrm{H}^{+}=\mathbf{H g}\left(\mathbf{C H}_{3}\right)_{2}(\mathbf{a q})+8 \mathrm{H}_{2} \mathrm{O}$ & 81.2 \\
\hline $\mathrm{Hg}(\mathrm{OH})_{2}+\mathrm{CO}_{3}^{2-}+8 \mathrm{e}^{-}+11 \mathrm{H}^{+}+\mathrm{Cl}^{-}=\mathbf{H g}\left(\mathbf{C H}_{3}\right) \mathbf{C l}+5 \mathrm{H}_{2} \mathrm{O}$ & 55.02 \\
\hline $\mathrm{Hg}(\mathrm{OH})_{2}+\mathrm{CO}_{3}{ }^{2-}+8 \mathrm{e}^{-}+10 \mathrm{H}^{+}=\mathbf{H g}\left(\mathbf{C H}_{3}\right) \mathbf{O H}+4 \mathrm{H}_{2} \mathrm{O}$ & 45.57 \\
\hline $\mathrm{Hg}(\mathrm{OH})_{2}+2 \mathrm{CO}_{3}{ }^{2-}+8 \mathrm{e}^{-}+11 \mathrm{H}^{+}=\mathbf{H g}\left(\mathbf{C H}_{3}\right) \mathbf{C O}_{3}^{-}+5 \mathrm{H}_{2} \mathrm{O}$ & 56.3 \\
\hline $\mathrm{Hg}(\mathrm{OH})_{2}+\mathrm{CO}_{3}{ }^{2-}+8 \mathrm{e}^{-}+11 \mathrm{H}^{+}+\mathrm{SO}_{4}{ }^{2-}=\mathbf{H g}\left(\mathrm{CH}_{3}\right) \mathrm{SO}_{4}^{-}+5 \mathrm{H}_{2} \mathrm{O}$ & 51.14 \\
\hline $\mathrm{Hg}(\mathrm{OH})_{2}+\mathrm{CO}_{3}^{2-}+8 \mathrm{e}^{-}+10 \mathrm{H}^{+}+\mathrm{HS}^{-}=\mathbf{H g}\left(\mathbf{C H}_{3}\right) \mathrm{S}^{-}+5 \mathrm{H}_{2} \mathrm{O}$ & 84. 14 \\
\hline $2 \mathrm{Hg}(\mathrm{OH})_{2}+2 \mathrm{CO}_{3}{ }^{2-}+17 \mathrm{e}^{-}+21 \mathrm{H}^{+}=\left(\mathbf{H g C H}_{3}\right)_{2} \mathbf{O H}+9 \mathrm{H}_{2} \mathrm{O}$ & 101.87 \\
\hline $2 \mathrm{Hg}(\mathrm{OH})_{2}+2 \mathrm{CO}_{3}{ }^{2-}+16 \mathrm{e}^{-}+21 \mathrm{H}^{+}+\mathrm{HS}^{-}=\left(\mathbf{H g C H}_{3}\right)_{2} \mathbf{S}+10 \mathrm{H}_{2} \mathrm{O}$ & 150.68 \\
\hline $\mathrm{Hg}(\mathrm{OH})_{2}+\mathrm{DOM}^{2-}+2 \mathrm{H}^{+}=\mathbf{H g}-\mathbf{D O M}+2 \mathrm{H}_{2} \mathrm{O}$ & 5.08 \\
\hline
\end{tabular}

Four model runs were conducted: $\mathrm{pH}-4$ and $0.002 \mathrm{mg} / \mathrm{L}$ total $\mathrm{Hg}$, $\mathrm{pH}-4$ and 0.2 $\mathrm{mg} / \mathrm{L}$ total $\mathrm{Hg}, \mathrm{pH}-7$ and $0.002 \mathrm{mg} / \mathrm{L}$ total $\mathrm{Hg}$, and $\mathrm{pH}-7$ and $0.2 \mathrm{mg} / \mathrm{L}$ total $\mathrm{Hg}$. These $\mathrm{pH}$ values were selected to represent a slightly more acid and more basic $\mathrm{pH}$ than what is typically expected at the site. As will be discussed in more detail in the Results and Discussion section (Section 3.0), the average field $\mathrm{pH}$ value that was determined for this study was 5.06 . The mercury concentration of $0.002 \mathrm{mg} / \mathrm{L}$ was selected because it's the 
Maximum Concentration Level (MCL) and it would provide a low mercury concentration for chemical speciation. The mercury concentration of $0.2 \mathrm{mg} / \mathrm{L}(200-\mu \mathrm{g} / \mathrm{L})$ was selected to simulate a scenario that might have existed when high concentrations were originally introduced into the site when the basin wall was breached or the subsurface plume initially entered the site. It was anticipated that the simulations using the higher mercury concentration would result in more mercury precipitation and therefore would provide some insight to the solid phases that might form at the site. For each model run, the redox was set to 33 values ranging between -200 and $+800 \mathrm{mV}$. Lower potentials were attempted, but the model would not converge for those selected potential values (a mathematical problem). The background aqueous chemistry in these simulations was based on concentrations reported for an uncontaminated surface water collected from an area adjacent to the operable unit (Kaplan and Serkiz 2000) (Table 2). To simplify presentation of the data, only those components present at concentrations $>1-\mu \mathrm{g} / \mathrm{L}$ were included in the figures. All data, including the $<1-\mu \mathrm{g} / \mathrm{L}$ data, is included in the Appendix. An important limitation of these types of calculations is that neither sorption nor microbial reactions are considered. The implications of these omissions are discussed in the Results and Discussion section (Section 3.0).

Table 2. Chemical Composition of Uncontaminated Surface Water Collected from Near the TNX Outfall Delta Operable Unit ${ }^{\mathrm{a}}$

\begin{tabular}{lcclcc}
\hline \multicolumn{2}{c}{$\begin{array}{c}\text { Constituent } \\
\text { Concentration } \\
(\mu \mathrm{g} / \mathrm{L})\end{array}$} & $\begin{array}{c}\text { Concentration } \\
(\mathrm{mM})\end{array}$ & Constituent & $\begin{array}{c}\text { Concentration } \\
(\mu \mathrm{g} / \mathrm{L})\end{array}$ & $\begin{array}{c}\text { Concentration } \\
(\mathrm{mM})\end{array}$ \\
\hline $\mathrm{pH}$ & 5.1 (unitless) & & $\mathrm{Na}$ & 357.28 & 0.016 \\
$\mathrm{Al}$ & 9.12 & 0.00034 & $\mathrm{Ni}$ & 1.29 & $2.2 \mathrm{E}-05$ \\
$\mathrm{As}$ & $<0.18$ & & $\mathrm{Se}$ & $<0.61$ & \\
$\mathrm{Ba}$ & 64.87 & 0.0005 & $\mathrm{Si}$ & 4395 & 0.1565 \\
$\mathrm{Ca}$ & 3850 & 0.0962 & $\mathrm{Sr}$ & 33.98 & 0.00039 \\
$\mathrm{Ce}$ & 0.087 & $6.2 \mathrm{E}-07$ & $\mathrm{Th}$ & 0.013 & $5.69 \mathrm{E}-08$ \\
$\mathrm{Co}$ & 0.065 & $1.1 \mathrm{E}-06$ & $\mathrm{TI}$ & 0.055 & $2.69 \mathrm{E}-07$ \\
$\mathrm{Cr}$ & $<0.92$ & & $\mathrm{U}$ & $<0.01$ & \\
$\mathrm{Cs}$ & 0.052 & $3.9 \mathrm{E}-07$ & $\mathrm{Chloride}$ & 2061 & 0.0598 \\
$\mathrm{Cu}$ & $<0.13$ & & Nitrate & 186 & 0.003 \\
$\mathrm{Eu}$ & 0.016 & $1 \mathrm{E}-07$ & Phosphate & $<100$ & \\
$\mathrm{Fe}$ & 99.3662 & 0.00178 & Nitrite & $<100$ & \\
$\mathrm{Hg}$ & 0.076 & $3.8 \mathrm{E}-07$ & Sulfate & 13690 & 0.214 \\
$\mathrm{~K}$ & 229.15 & 0.0058 & Inorganic C & $<100$ & \\
$\mathrm{Mg}$ & 1117.89 & 0.046 & Organic C & 6051 & 0.504 \\
$\mathrm{Mn}$ & 57.9 & 0.001 & Summation of Cations & 0.325 \\
& & & Summation of Anions & 0.277 \\
\hline
\end{tabular}

\footnotetext{
${ }^{a}$ Surface water sample collected about $1000-\mathrm{m}$ north of the northern boundary of the
} operable unit. 


\subsection{Sample Analysis and Quality Assurance}

The standard QA practices described in the WSRC QA Manual 1Q were followed throughout this study. Commercial computer software packages (e.g., Microsoft Excel) were used for many of the calculations. The software calculations were validated and verified by hand calculations. The MINTEQA2 software was verified by EPA (Allison et al. 1981). All calculations are considered (General Service) GS calculations. Control of waste products from these activities followed Procedure 6.01 in Manual L1.

\section{Results and Discussion}

\subsection{Redox Measurements}

The results from the Eh measurements made from the surface sediments are presented in Table 3. The $42 \mathrm{Eh}$ values ranged from 39 to $727 \mathrm{mV}$ and averaged $399 \pm$ $18 \mathrm{mV}$. The 42-pH values ranged from 3.60 to 6.16 and a median of 5.27. The Eh values are within the expected range of values for mildly acid sediments (Baas-Becking et al. 1960). Baas-Becking et al. (1960) conducted a classic study in which they tabulated $>6,200 \mathrm{pH}$ and Eh paired values of natural soil/sediment systems reported in the literature. They identified a number of empirical relationships and closely related these relationships to thermodynamic constructs. Perhaps more importantly, they identified the likely "pH-Eh space" in the natural environment. For pH 5, the Eh range identified by Baas-Becking et al. was approximately -40 to $675 \mathrm{mV}$. All but one value in Table 3, 727 $\mathrm{mV}$, is within this range.

The sediment descriptions can be used to provide some indication of the presence or absence of Fe(III) coatings and organic matter. Sediments characterized as orange might be expected to contain Fe(III) coatings, which in turn suggest that the iron in the sediments exists primarily in an oxidized form. Sediments characterized as being organic, or having a dark color, gleyed, might be expected to be a stronger reducing environment. In fact, the sediments with higher organic matter contents tended to have lower Eh values. For example, two measurements made within 2 meters from each other, Bgch-7a and Bgch-7b, had appreciably different organic matter contents. Sample Bgch$7 \mathrm{a}$ was an orange sand, suggesting it had Fe(III) coatings and an oxidized environment. Sample Bgch-7b had a darker color, suggesting it contained high concentrations of organic matter and a more reducing environment. The Eh of the orange sand, Bgch-7a, was $400 \pm 10 \mathrm{mV}$, whereas the Eh of the nearby organic sediment, Bgch-7b, was $83 \pm 39$ $\mathrm{mV}$. Another important implication of these measurements is that the Eh values vary greatly and that the microenvironment of the sediment greatly influences the redox potential. 
Eh and $\mathrm{pH}$ measurements were taken at four depth at two locations (Table 4). Both locations were outside the contaminated operable unit. One location, $0-21$, was submerged on the sampling date. The other location, Bgch-5, was not submerged and was located on a ridge that was $\sim 5-\mathrm{m}$ higher than $0-21$. Unexpectedly, the Eh values at the two sites do not vary greatly. The lowest Eh value was measured in the lowest sample at both sites. 
Table 3. Field Redox and pH Values Measured from Surface Sediments at the TNX Outfall Delta Conducted on January $29,2000$.

\begin{tabular}{|c|c|c|c|c|c|c|c|c|c|}
\hline ID\# & Soil Description & Rep & $\begin{array}{c}\text { Temp. } \\
{ }^{\circ} \mathrm{C}\end{array}$ & $\mathrm{pH}$ & $\begin{array}{l}\text { Eh } \\
(\mathrm{mV})\end{array}$ & $\begin{array}{l}\text { Avg. Eh } \\
\text { (mV) }\end{array}$ & $\begin{array}{l}\text { Std. Dev. Eh } \\
(\mathrm{mV})\end{array}$ & Avg pH & $\begin{array}{c}\text { Std. Dev. } \\
\text { pH }\end{array}$ \\
\hline \multirow[t]{2}{*}{ B-3 } & Highly organic, sandy & 1 & 1.6 & 5.74 & 389 & 390 & 1 & 5.8 & 0.1 \\
\hline & & 2 & 1.5 & 5.9 & 390 & & & & \\
\hline \multirow[t]{2}{*}{$C-3$} & sandy, some organic & 1 & 5.7 & 5.07 & 450 & 445 & 7 & 5.2 & 0.2 \\
\hline & & 2 & 4.8 & 5.4 & 440 & & & & \\
\hline \multirow[t]{2}{*}{$C-5$} & sandy & 1 & 3.2 & 5.45 & 366 & 373 & 10 & 5.5 & 0.0 \\
\hline & & 2 & 2.7 & 5.47 & 380 & & & & \\
\hline \multirow[t]{2}{*}{ B-6 } & sandy orange & 1 & 2.4 & 5.78 & 440 & 435 & 7 & 5.8 & 0.0 \\
\hline & & 2 & 2.4 & 5.81 & 430 & & & & \\
\hline \multirow[t]{2}{*}{$A-5$} & heavy clay & 1 & 2.5 & 5.22 & 401 & 409 & 11 & 5.2 & 0.0 \\
\hline & & 2 & 2.3 & 5.2 & 416 & & & & \\
\hline \multirow[t]{2}{*}{ A-4 } & organic clay & 1 & 2.9 & 5.28 & 377 & 388 & 16 & 5.3 & 0.0 \\
\hline & & 2 & 2.5 & 5.34 & 399 & & & & \\
\hline \multirow[t]{2}{*}{ B-5 } & sandy orange & 1 & 4 & 5.51 & 440 & 443 & 4 & 5.5 & 0.0 \\
\hline & & 2 & 4.1 & 5.56 & 445 & & & & \\
\hline \multirow[t]{2}{*}{ B-8 } & clay & 1 & 4.8 & 5.42 & 392 & 401 & 13 & 5.4 & 0.0 \\
\hline & & 2 & 5.6 & 5.45 & 410 & & & & \\
\hline \multirow[t]{2}{*}{ D-7 } & organic clay & 1 & 3.6 & 5.25 & 390 & 405 & 21 & 5.2 & 0.0 \\
\hline & & 2 & 3.8 & 5.23 & 420 & & & & \\
\hline \multirow[t]{2}{*}{$C-10$} & organic clay & 1 & 3.9 & 6.16 & 330 & 350 & 28 & 6.1 & 0.1 \\
\hline & & 2 & 3.5 & 6 & 370 & & & & \\
\hline \multirow[t]{2}{*}{ D-28 } & sandy, orange & 1 & 5.8 & 5.46 & 410 & 413 & 4 & 5.5 & 0.0 \\
\hline & & 2 & 5.8 & 5.46 & 415 & & & & \\
\hline L-26 & organic sandy & 1 & 4.9 & 5.3 & 375 & 375 & -- & 5.3 & --- \\
\hline I-14 & orange sandy & 1 & 7.6 & 5.98 & 385 & 385 & --- & 6.0 & -- \\
\hline G-13 & organic sandy & 1 & 9 & 5.05 & 387 & 387 & --- & 5.1 & -- \\
\hline G-11 & organic clay & 1 & 7.4 & 5.49 & 410 & 410 & --- & 5.5 & --- \\
\hline$[-11]$ & heavy clay & 1 & 7.5 & 5.71 & 360 & 360 & --- & 5.7 & --- \\
\hline \multirow[t]{3}{*}{ Bgch-7a } & surface orange șand & 1 & 20 & 4.2 & 407 & 400 & 10 & 4.2 & 0.1 \\
\hline & & 2 & 20 & 4.3 & 388 & & & & \\
\hline & & 3 & 20 & 4.2 & 405 & & & & \\
\hline \multirow[t]{3}{*}{ Bgch-7b } & surface organic & 1 & 20 & 3.6 & 39 & 83 & 39 & 3.7 & 0.1 \\
\hline & & 2 & 19.8 & 3.8 & 99 & & & & \\
\hline & & 3 & 19.8 & 3.6 & 112 & & & & \\
\hline \multirow[t]{3}{*}{$K-26$} & surface organic sandy & 1 & 19.8 & 4.5 & 670 & 691 & 32 & 4.5 & 0.1 \\
\hline & & 2 & 20 & 4.6 & 675 & & & & \\
\hline & & 3 & 20 & 4.4 & 727 & & & & \\
\hline \multirow[t]{3}{*}{ A-32 } & surface organic sandy & 1 & 20 & 4.5 & 422 & 431 & 9 & 4.5 & 0.1 \\
\hline & & 2 & 20 & 4.6 & 430 & & & & \\
\hline & & 3 & 20 & 4.4 & 440 & & & & \\
\hline \multirow[t]{3}{*}{ A-30 } & surface sandy organic & 1 & 20 & 4.3 & 390 & 381 & 8 & 4.3 & 0.1 \\
\hline & & 2 & 20 & 4.4 & 375 & & & & \\
\hline & & 3 & 20 & 4.3 & 378 & & & & \\
\hline
\end{tabular}


Table 4. Field Redox and pH Values Measured at four Depths and two Locations at the TNX Outfall Delta Conducted on January $12,2000 .^{\mathrm{a}}$

\begin{tabular}{|c|c|c|c|c|c|c|c|c|c|c|}
\hline ID\# & $\begin{array}{l}\text { Depth } \\
\text { (cm) }\end{array}$ & Soil Description & Rep & $\begin{array}{c}\text { Temp. } \\
\left({ }^{\circ} \mathrm{C}\right)\end{array}$ & $\mathrm{pH}$ & $\begin{array}{c}\mathrm{Eh} \\
(\mathrm{mV})\end{array}$ & $\begin{array}{c}\text { Avg. } \\
\text { Eh (mV) }\end{array}$ & $\begin{array}{l}\text { Std. Dev. } \\
\text { Eh (mV) }\end{array}$ & $\begin{array}{l}\text { Avg. } \\
\mathrm{pH}\end{array}$ & $\begin{array}{c}\text { Std. Dev. } \\
\text { pH }\end{array}$ \\
\hline \multirow{8}{*}{$0-21$} & 0 to 8 & Surface/organic & 1 & 19 & 3.47 & 480 & 480 & 0 & 3.50 & 0.04 \\
\hline & & & 2 & 18.8 & 3.52 & 480 & & & & \\
\hline & 8 to 18 & Gley layer & 1 & 18 & 3.91 & 483 & 492 & 12 & 3.90 & 0.02 \\
\hline & & & 2 & 18 & 3.88 & 500 & & & & \\
\hline & 18 to 40 & Orange sandy, water table & 1 & 18 & 4.02 & 510 & 508 & 4 & 4.02 & 0.00 \\
\hline & & & 2 & 18 & 4.02 & 505 & & & & \\
\hline & 40 to 56 & Below water table, Fe-oxide layer & 1 & 19.5 & 4.37 & 470 & 461 & 13 & 4.32 & 0.07 \\
\hline & & & 2 & 19.5 & 4.27 & 452 & & & & \\
\hline \multirow[t]{8}{*}{ BGCH-5 } & 0 to 1 & Surface/organic & 1 & 20 & 4.54 & 405 & 404 & 2 & 4.44 & 0.15 \\
\hline & & & 2 & 19.5 & 4.33 & 402 & & & & \\
\hline & 1 to 23 & Orange brown sandy clay & 1 & 20 & 4.5 & 414 & 415 & 1 & 4.50 & 0.00 \\
\hline & & & 2 & 20 & 4.5 & 416 & & & & \\
\hline & 23 to 33 & Gray/green clay layer within orange sandy clay & 1 & 20 & 4.54 & 397 & 395 & 4 & 4.56 & 0.02 \\
\hline & & & 2 & 20 & 4.57 & 392 & & & & \\
\hline & 33 to 41 & Gray/green clay layer & 1 & 20 & 4.56 & 384 & 385 & 1 & 4.52 & 0.06 \\
\hline & & & 2 & 20 & 4.47 & 385 & & & & \\
\hline
\end{tabular}

${ }^{\mathrm{a}}$ On January 12, 2000, when these measurements were taken, Sample O-21 was submerged, and Sample Bgch-5 was on an elevated portion of the site, clearly not part of the wetland. 


\subsection{Mercury Speciation Calculations}

There are two important caveats that must be kept in mind while evaluating the thermodynamic chemical speciation results presented in this section. The first is that the influence of microbes on mercury speciation is not included in the calculations. As mentioned in the introduction, microbes could reduce mercury from an oxidation state of +2 to 0 (the reduction to +1 is not common; Benes and Havlik 1979). Microbes may also methylate mercury. This is especially important to the risk analysis being conducted at the site because these mercury species are especially toxic. It is generally believed that microbes can methylate only dissolved mercury species, mercury species that are loosely retained on sediment surfaces (perhaps by cation exchange), or some mercury associated with the organic fraction (Beijer and Jernelov 1979). Since, only 0 to $8 \%$ of the total $\mathrm{Hg}$ in these sediments are associated with these soil fractions (Kaplan and Serkiz 2000), it is likely that biotic methylation will play only a small role in mercury chemistry at the site. The other important caveat to keep in mind while evaluating the thermodynamic calculations presented in this section is that the presence of a sorbing solid phase is not included in the modeling. This is perhaps a more important factor, since mercury typically sorbs to sediments very strongly, as discussed in the Introduction section. By reducing the amount of dissolved mercury, the sediments would be reducing the amount of mercury available for microbes to act on and would reduce the amount of mercury in the mobile phase.

Mercury speciation calculations were conducted for four different scenarios: $\mathrm{pH}-4$ and $0.002 \mathrm{mg} / \mathrm{L}$ total $\mathrm{Hg}$ (Figure 2), $\mathrm{pH}-4$ and $0.2 \mathrm{mg} / \mathrm{L}$ total $\mathrm{Hg}$ (Figure 3), $\mathrm{pH}-7$ and $0.002 \mathrm{mg} / \mathrm{L}$ total $\mathrm{Hg}$ (Figure 4), and pH-7 and $0.2 \mathrm{mg} / \mathrm{L}$ total $\mathrm{Hg}$ (Figure 5).

The dominant species in the $\mathrm{pH}-4$ and $0.002 \mathrm{mg} / \mathrm{L}$ total $\mathrm{Hg}$ system (Figure 2) were $\mathrm{Hg}\left(\mathrm{CH}_{3}\right) \mathrm{S}^{-}(\mathrm{aq}), \mathrm{HgS}(\mathrm{s}), \mathrm{Hg}^{2+}(\mathrm{aq}), \mathrm{HgCl}_{2}(\mathrm{aq}), \mathrm{HgCl}_{3}{ }^{-}(\mathrm{aq})$, and $\mathrm{HgCl}_{4}{ }^{2-}$ (aq). Throughout this report, the notation "(aq)" indicates that the species is dissolved in the aqueous phase and "(s)" indicates that it exists as a solid. Of these species, $\mathrm{Hg}\left(\mathrm{CH}_{3}\right) \mathrm{S}$ ( $(\mathrm{aq})$ is not likely to exist at the site because the Eh values required for its formation is very unlikely to occur in the site's mildly acidic environment. The presence of $\mathrm{Cl}^{-}$has a significant effect on the mercury speciation, especially at elevated Eh values. This has been reported by other experimentalists and modelers (reviewed by Andersson 1979, Schuster 1991, Yin et al. 1996). $\mathrm{Hg}^{2+}(\mathrm{aq})$ is calculated to exist in moderate reducing conditions. Several researchers have noted that $\mathrm{Hg}^{2+}$ rarely exists in sediment porewater as a free ion due to its propensity to sorb to solids or form complexes, especially to chloride or organic matter (Schuster 1991, Wallschlager et al. 1998a, Wallschlager at al. 1998b). From the stand point of the risk analyses being conducted at this site, if the model system is reduced, then dissolved mercury is expected to be removed from solution as $\mathrm{HgS}$, a sparingly soluble solid, making the mercury less mobile and less toxic than in the oxidized environment. Somewhat surprising is that no dissolved organic-mercury species are predicted to be formed. This is true under all conditions that were simulated. The lack of a dissolved organic-mercury complex is consistent with the field measurement that very little mercury is in the aqueous phase (Kaplan and Serkiz 2000). 


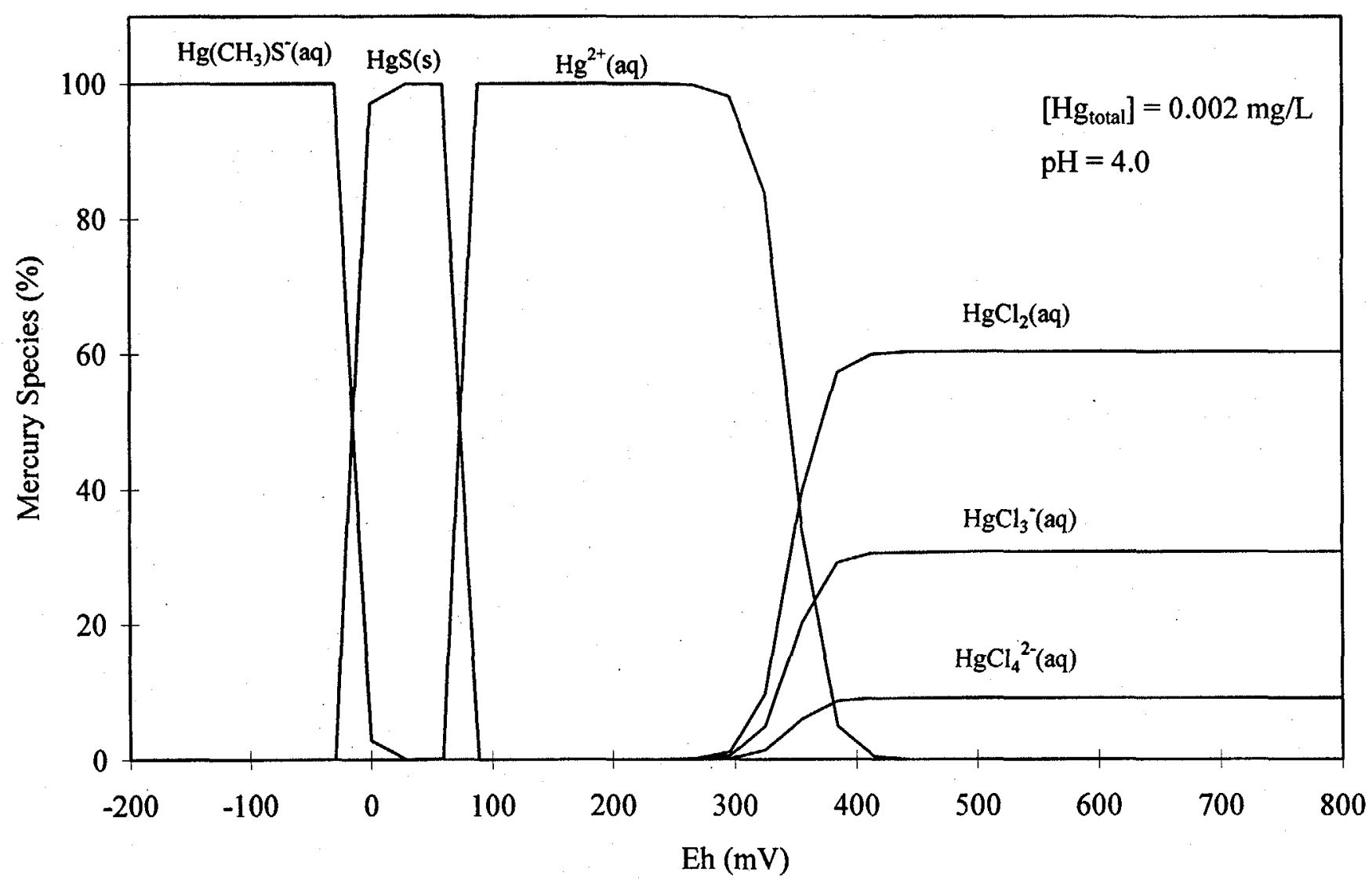

Figure 2. Mercury speciation as a function of redox potential (as estimated by the standard platinum electrode potential, for which, greater the value, the more oxidized the system) in TNX surface water (Table 2) at $\mathrm{pH} 4$ and total $\mathrm{Hg}$ concentration of $0.002 \mathrm{mg} / \mathrm{L}$. The range of redox potentials likely in most soils at pH 4 is 0 to $600 \mathrm{mV}$ (Baas-Becking et al 1960). 


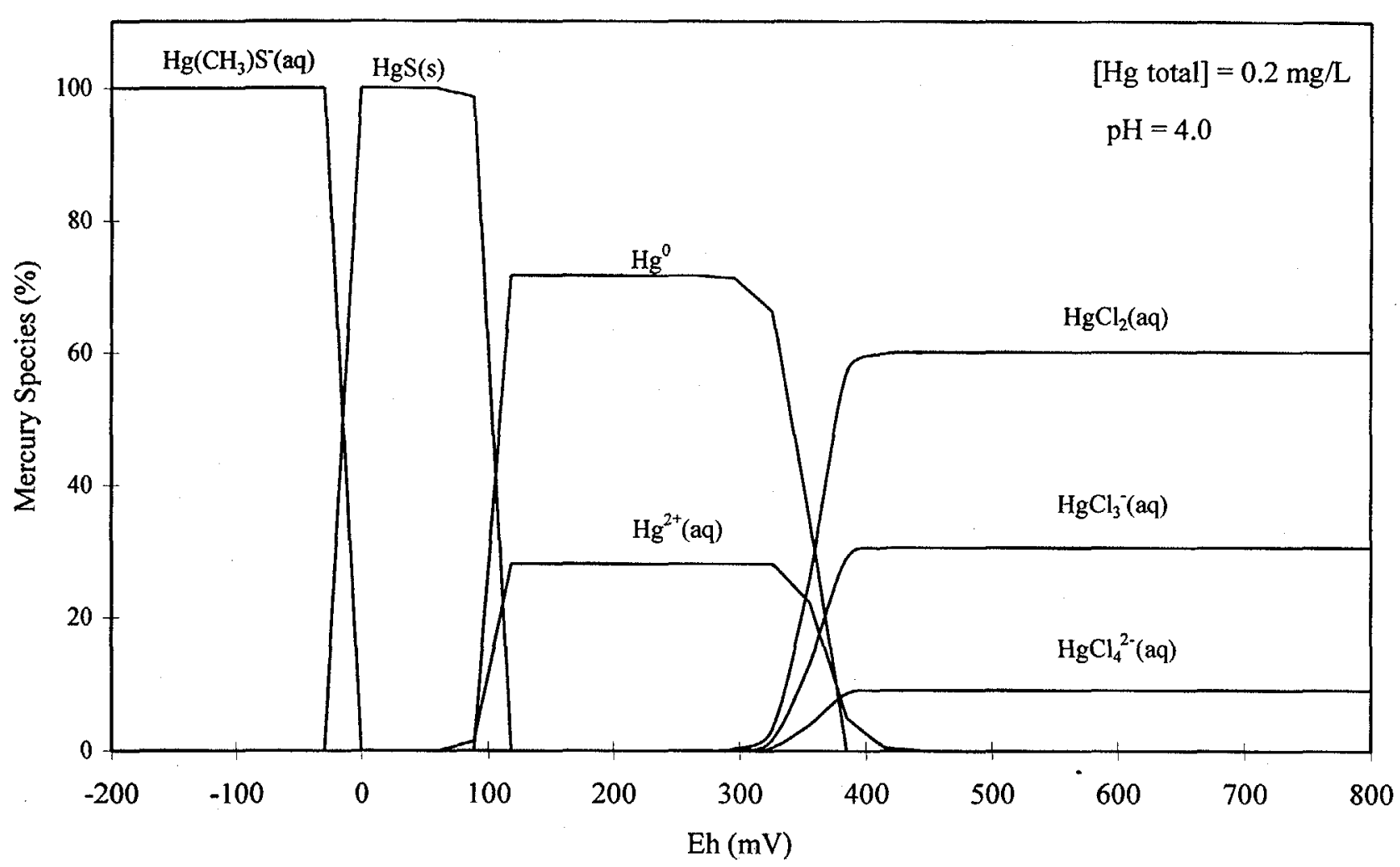

Figure 3. Mercury speciation as a function of redox potential (as estimated by the standard platinum electrode potential, for which, greater the value, the more oxidized the system) in TNX surface water (Table 2) at pH 4 and total $\mathrm{Hg}$ concentration of $0.2 \mathrm{mg} / \mathrm{L}$. The range of redox potentials likely in most soils at $\mathrm{pH} 4$ is 0 to $600 \mathrm{mV}$ (Baas-Becking et al 1960). 


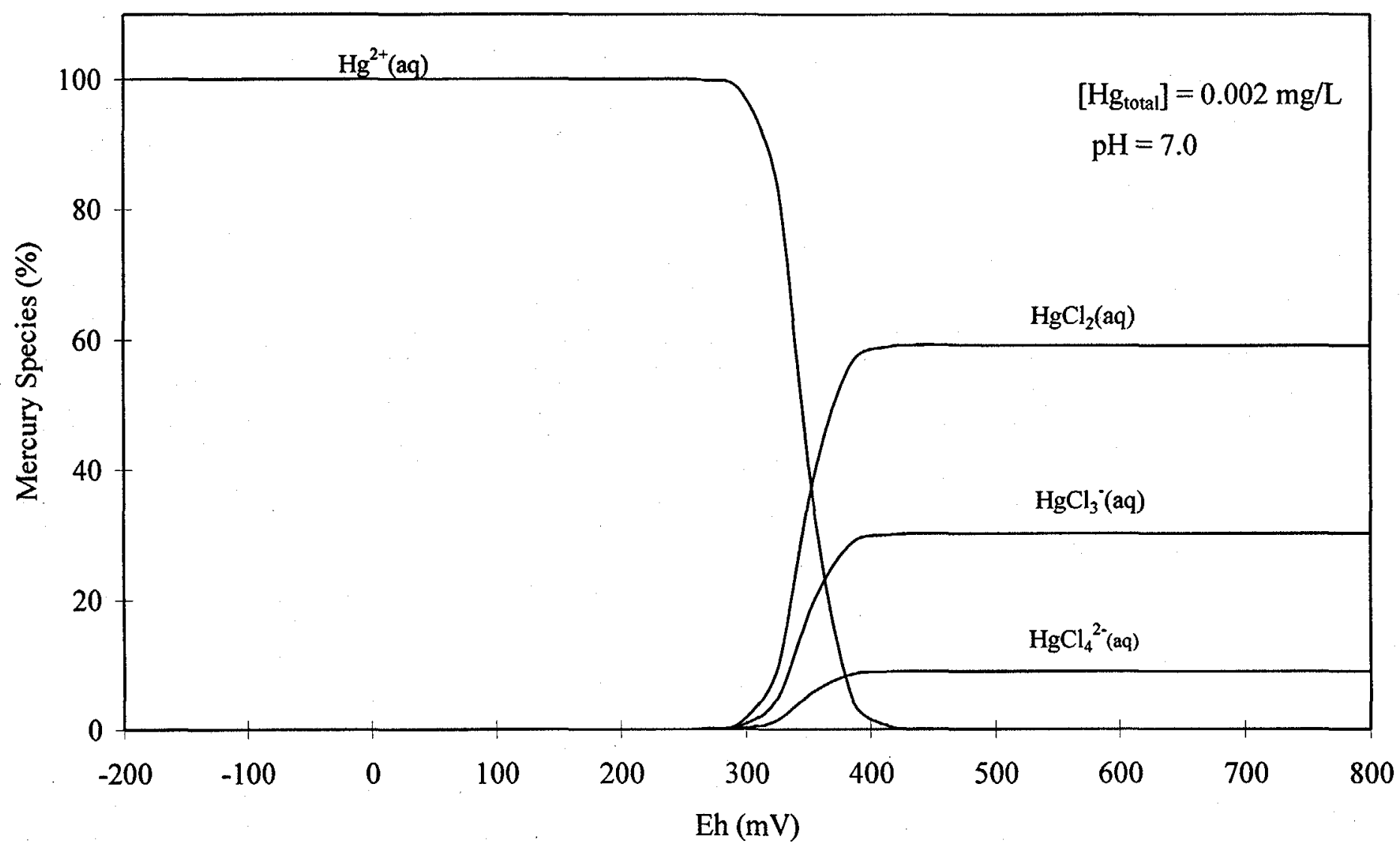

Figure 4. Mercury speciation as a function of redox potential (as estimated by the standard platinum electrode potential, for which, greater the value, the more oxidized the system) in TNX surface water (Table 2) at pH 7 and total $\mathrm{Hg}$ concentration of $0.002 \mathrm{mg} / \mathrm{L}$. The range of redox potentials likely in most soils at pH 7 is -350 to $650 \mathrm{mV}$ (Baas-Becking et al 1960). 


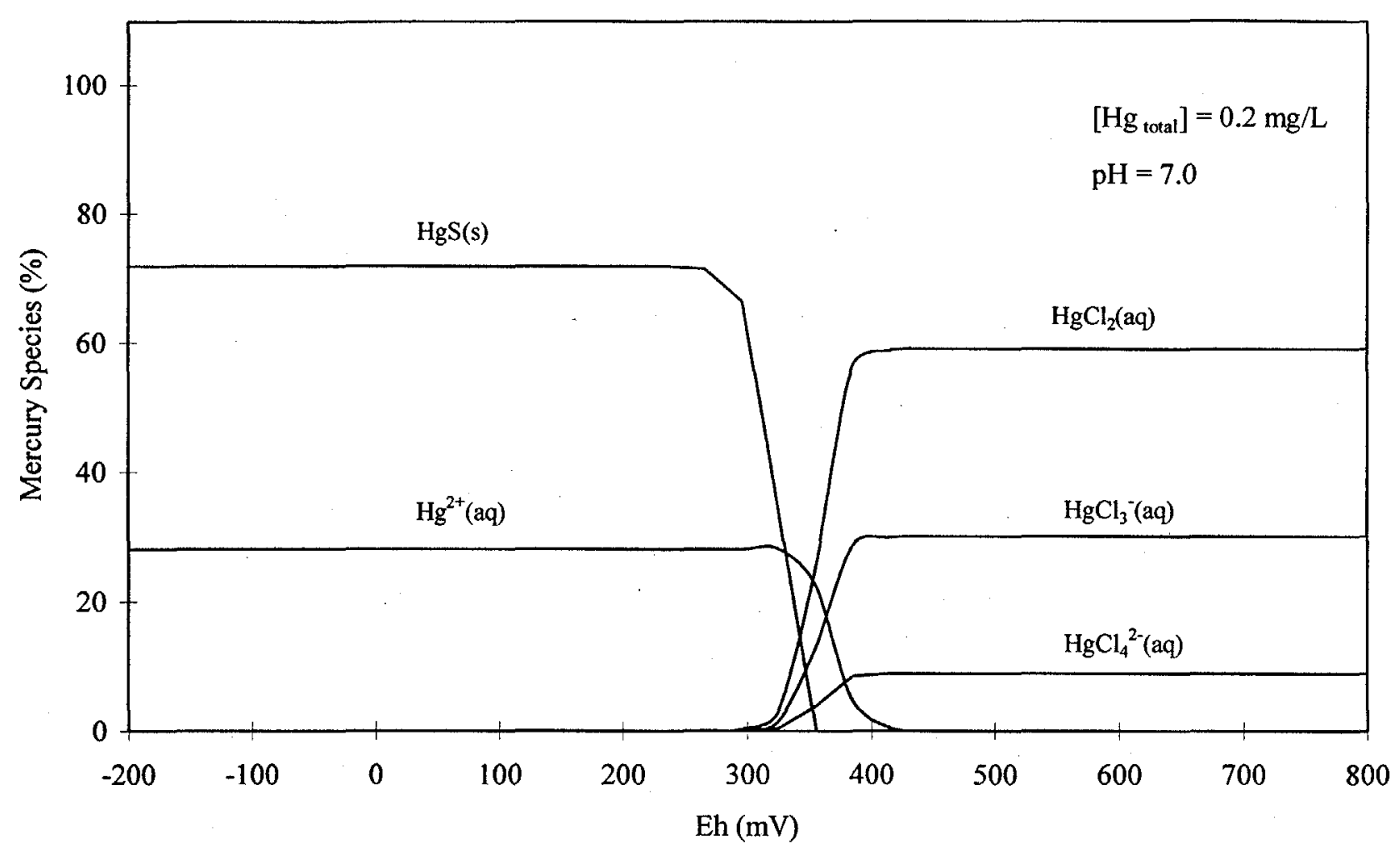

Figure 5. Mercury speciation as a function of redox potential (as estimated by the standard platinum electrode potential, for which, greater the value, the more oxidized the system) in TNX surface water (Table 2) at $\mathrm{pH} 7$ and total $\mathrm{Hg}$ concentration of $0.2 \mathrm{mg} / \mathrm{L}$. The range of redox potentials likely in most soils at $\mathrm{pH} 7$ is -350 to $650 \mathrm{mV}$ (Baas-Becking et al. 1960). 
The dominant species in the $\mathrm{pH}-4$ and $0.2 \mathrm{mg} / \mathrm{L}$ total $\mathrm{Hg}$ system (Figure 3 ) include those formed in the lower $\mathrm{Hg}$ concentration system and $\mathrm{Hg}^{0}$. Thus, at $0.2 \mathrm{mg} / \mathrm{L}$ total $\mathrm{Hg}$, simulating the introduction of the contaminant plume into the wetland area, between 76 and $100 \%$ of the mercury would be expected to precipitate as $\mathrm{HgS}$ or $\mathrm{Hg}^{0}$ under reducing site conditions $(\sim 50$ to $\sim 250 \mathrm{mV})$. $\mathrm{Hg}^{0}$ is an extremely complex species in that it precipitates to form a liquid and it can easily enter the gas phase. Essentially no $\mathrm{Hg}^{0}$ is expected to exist in the aqueous phase because of its strong vapor pressure (Benes and Havlik 1979).

The dominant species in the $\mathrm{pH}-7$ and $0.002 \mathrm{mg} / \mathrm{L}$ total $\mathrm{Hg}$ system (Figure 4) include $\mathrm{Hg}^{2+}(\mathrm{aq}), \mathrm{HgCl}_{2}$ (aq), $\mathrm{HgCl}_{3}{ }^{-}(\mathrm{aq})$, and $\mathrm{HgCl}_{4}{ }^{2-}(\mathrm{aq})$. Importantly, no solid mercury phases were predicted to precipitate, thereby making more of the mercury in the system available for remaining in the mobile (and more toxic) aqueous phase. The major difference between the $\mathrm{pH}-7$ systems with 0.002 (Figure 4 ) and $0.2 \mathrm{mg} / \mathrm{L}$ ((Figure 5) total $\mathrm{Hg}$, is that in the latter, greater than $70 \%$ of the $\mathrm{Hg}$ precipitated as $\mathrm{HgS}(\mathrm{s})$. Thus, an appreciable proportion of the mercury precipitates in the systems with $0.2 \mathrm{mg} / \mathrm{L}$ total $\mathrm{Hg}$, irrespective of whether the $\mathrm{pH}$ is 4 or 7 .

Laboratory studies could be conducted to validate the modeling results by directly measuring mercury speciation using spectroscopic and voltammetric techniques. The predicted absence of methylated mercury compounds in the oxidized and reduced systems could be confirmed through the use of cold-vapor atomic fluorescence spectroscopic techniques.

\section{Conclusions}

Because the cost of conducting desorption and toxicity tests under reducing conditions would be expensive and time consuming, it was decided to attempt to evaluate this issue through the use of thermodynamic speciation calculations based on site-specific data. Four sets of calculations were conducted (each set comprising 33 individual calculations), whereby the dominant mercury species were estimated thermodynamically as a function of the redox potential. Attempts were made to relate the results to experimental results reported in the literature. Additionally, 58 field measurements of Eh were made in sediments at or adjacent to the TNX Outfall Delta waste site. Because no Eh measurements had been made at the study site, the measured Eh values provided an indication of the range of likely values that may exist at the study site. These values spanned the range of expected values for slightly acidic sediment systems.

The speciation calculation indicated that as the redox potential decreased, the availability of mercury tended to decrease due to the formation of $\mathrm{HgS}$, a sparingly soluble precipitate. No abiotic methylated mercury was formed within the range of likely 
redox levels for this mildly acidic site. This is an important finding because methylated mercury is highly toxic. As the $\mathrm{pH}$ of the system increased, less mercury was predicted to precipitate, thereby leaving more in the mobile and bioavailable aqueous phase.

In conclusion, the results from this work suggest mercury would likely become more strongly retained by the solid phase under reducing conditions than under oxidizing conditions at the TNX Outfall Delta Operable Unit. Considering that experimental results indicate that mercury is extremely tightly bound to the solid phase under oxidizing conditions, little mercury mobility would therefore be expected under reducing conditions. Additionally, these calculations suggest that little additional methylated mercury should be expected when the system becomes reduced. The mildly acid conditions of the site are a natural deterrent to the formation of mobile and toxic mercury species under reducing conditions due to the formation of $\mathrm{HgS}$, a sparingly soluble solid.

\section{References}

Alberts, J. J., J. E. Schindler, R. W. Miller, and D. E. Nutter, Jr. 1974. Elemental Mercury Evolution Mediated by Humic Acid. Science. 194:895-896.

Allison, J. D.; Brown, D. S.; Gradac, K. J. (1991) MINTEQA2/PRODEFA2, a Geochemical Assessment Model for Environmental Systems: Version 3.0 Users Manual. Washington, D. C.: U. S. Government Printing Office. EPA/600/3-91/021.

Andersson, A. 1979. Mercury in Soils. In: J. O. Nriagu (ed.), The Biogeochemistry of Mercury in the Environment. Elsevier, Amsterdam. pp. 79-112.

Baas-Becking, L. G. M., I. R. Kaplan, and D. Moore. 1960. Limits of the Natural Environment in Terms of $\mathrm{pH}$ and Oxidation-reduction Potentials. J. Geology. 68:243284.

Beijer, K., and A. Jernelov. 1979. Methylation of Mercury in Aquatic Environments. In: J. Nriagu (ed.) The Biogeochemistry of Mercury in the Environment. Elsevier, NorthHolland Biomedical Press, Amsterdam. pp. 203-210.

Benes, P., and B. Havlik. 1979. Speciation of Mercury in Natural Waters. In: J. O. Nriagu (ed.), The Biogeochemistry of Mercury in the Environment. Elsevier, NorthHolland Biomedical Press, Amsterdam. pp. 176-202.

Cheam, V. and Gamble, D.S. (1974) Metal-fulvic Acid Chelation Equilibrium in Aqueous $\mathrm{NaNO}_{3}$ Solution. $\mathrm{Hg}(\mathrm{II}), \mathrm{Cd}(\mathrm{II})$, and $\mathrm{Cu}(\mathrm{II})$ Fulvate Complexes. Can. J. Soil Sci. 54: $413-417$ 
Gjessing, E. T. 1976. Physical and Chemical Characteristics of Aquatic Humus. Ann Arbor Science, Ann Arbor, Michigan.

Hem, J. D. 1970. Chemical Behavior of Mercury in Aqueous Media. In: Mercury in the Environment, US Geological Survey Profile Paper. 713: 19-24.

Jernelov, A. 1972. Factors in the Transformation of Mercury to Methylmercury. In: R. Hartung and B. D. Dinman (eds.), Environmental Mercury Contamination. Ann Arbor. Sci. Publ. Inc., Ann Arbor, Michigan. pp. 167-172.

Kaplan, D. I., and S. M. Serkiz. 2000. In-situ Kd Values and Geochemical Behavior for Inorganic and Organic Constituents of Concern at the TNX Outfall Delta. WSRC-TR-9900488. Aiken, SC.

Lindsay, W. L. 1971. Chemical Equilibria in Soils. John Wiley \& Sons, New York. pp. 343-363.

Lockwood, R. A., and K. Y. Chen. 1973. Adsorption of $\mathrm{Hg}$ (II) by Hydrous Manganese Oxides. Environ. Sci. Technol. 7:1028-1034.

Newton, D. W., R. Ellis, and G. M. Paulsen. 1976. Effect of pH and Complex Formation of Mercury(II) Adsorption to Bentonite. J. Environ. Qual. 5:251-254.

Patrick, W. H., R. P. Gambrell, and S. P. Faulkner. 1996. Redox Measurements in Soils. In: Sparks, D. L. (ed.) Methods of Soil Analysis, Part 3, Chemical Methods. Soils Science Society of America, Inc., Madison, Wisconsin. pp. 1255-1274.

Reimers, R. S., and P. A. Krenkel. 1974. Kinetics of Mercury Adsorption and Desorption in Sediments. J. Water Pollut. Control Fed. 46:352-365.

Reimers, R. S., P. A. Krenkel, M. Eagle, and G. Tragitt. 1974. Sorption Phenomenon in the Organics of Bottom Sediments. In: Krenkel, P. A. (ed.), Heavy Metals in the Aquatic Environment. Pergamon Press, Oxford, pp. 335-337.

Schuster, E. 1991. The Behavior of Mercury in the Soil with Special Emphasis of Complexation and Adsorption Processes - A Review of the Literature. Water Air, and Soil Pollution. 56:667-680.

Specht, W. L. 1999. Results of Toxicity Tests and Chemical Analyses Conducted on Sediments Collected from the TNX Outfall Delta Operable Unit, July 1999. WSRC-TR99-00380. Aiken, SC.

Sposito, G. 1994. Chemical Equilibria and Kinetics in Soils. Oxford University Press, New York. 
Steinnes, E. 1990. Mercury. In: B. J. Alloway (ed.), Heavy Metals in Soils. John Wiley \& Sons, Inc., New York. pp. 222-236.

Stumm, W. and J. J. Morgan. 1981. Aquatic Chemistry An Introduction Emphasizing Chemical Equilibria In Natural Waters. Wiley-Interscience, New York.

Thomas, G. W. 1996. Soil pH and Soil Acidity. In: Dl. L. Sparks (ed.), Methods of Soil Analysis, Part 3 Chemical Methods. Soil Science Society of America, Inc., Madison, Wisconsin, pp. 475-491.

Turner, D.R. (1993) Mechanistic Approaches to Radionuclide Sorption Modeling. CNWRA 93-019. San Antonio, TX: Center for Nuclear Waste Regulatory Analyses.

Van Faassen, J. G. 1973. Effects of Mercury Compounds on Soil Microbes. Plant Soil. 38:485-487.

Wallschlager, D., M. V. M. Desai, M. Spenger, and R Wilken. 1998a. Mercury Speciation in Floodplain Soils and Sediments along a Contaminated River Transect. J. Environ. Qual. 27:1034-1044.

Wallschlager, D., M. V. M. Desai, M. Spengler, C. C. Windmoler, and R. Wilken. 1998b. How Humic Substances Dominate Mercury Geochemistry in Contaminated Floodplain Soils and Sediments. J. Environ. Qual. 27: 1044-1054.

WSRC. 1999a. 1998 Comprehensive TNX Area Annual Groundwater and Effectiveness Monitoring Report. WSRC-RP-99-4003. Aiken, SC.

WSRC. 1999b. RFI/RI with BRA for the TNX Outfall Delta, Lower Discharge Gully and Swamp Operable Unit. WSRC-RP-98-4158, Rev. 0. July 1999. Aiken, SC.

Yin, Y, H. E. Allen C. P. Huang, and P. F. Sanders. 1997. Adsorption/desorption Isotherms of $\mathrm{Hg}(\mathrm{II})$ by Soil. Soil Sci. 162:35-45.

Yin, Y., H. E. Allen, Y. Li, C. P. Huang, and P. F. Sanders. 1996. Adsorption of Mercury(II) by Soils: Effects of $\mathrm{pH}$, Chloride, and Organic Matter. J. Environ. Qual. 25:837-844.

Zepp, R. G., G. L. Baughman, N. L. Wolfe, and D. M. Cline. 1974. Methylmercuric Complexes in Aquatic Systems. Environ. Lett. 6:117-127. 

Appendix: Thermodynamic Speciation Results 
Table A1. Mercury Speciation at pH of 4 and Total Mercury Concentration of $0.002 \mathrm{mg} / \mathrm{L}$ (Data Used in Figure 2).

\begin{tabular}{|c|c|c|c|c|c|c|c|c|c|c|}
\hline $\mathrm{pE}$ & $\begin{array}{c}\text { Eh } \\
(\mathrm{mV})\end{array}$ & $\begin{array}{l}\text { Conc. (M) } \\
\mathrm{Hg}\left(\mathrm{CH}_{3}\right) \mathrm{S}^{-}\end{array}$ & $\begin{array}{c}\text { Percent } \\
\mathrm{Hg}\left(\mathrm{CH}_{3}\right) \mathrm{S}^{-}\end{array}$ & $\begin{array}{l}\text { Conc. (M) } \\
\mathrm{Hg}(\mathrm{HS})_{2}\end{array}$ & $\begin{array}{l}\text { Percent } \\
\mathrm{Hg}(\mathrm{HS})_{3}\end{array}$ & $\begin{array}{l}\text { Conc. (M) } \\
\mathrm{HgCl}_{2}(\mathrm{aq})\end{array}$ & $\begin{array}{c}\text { Percent } \\
\mathrm{HgCl}_{2} \text { (aq) }\end{array}$ & $\begin{array}{c}\text { Conc. (M) } \\
\mathrm{HgCl}_{3}^{-}\end{array}$ & $\begin{array}{l}\text { Percent } \\
\mathrm{HgCl}_{3}^{-}\end{array}$ & $\begin{array}{c}\text { Conc. (M) } \\
\mathrm{HgCl}_{4}^{2-}\end{array}$ \\
\hline-2 & -200 & 9.97E-09 & $1.00 \mathrm{E}+02$ & $3.57 \mathrm{E}-24$ & $3.58 \mathrm{E}-14$ & $2.45 \mathrm{E}-44$ & $2.46 \mathrm{E}-34$ & $1.26 \mathrm{E}-44$ & $1.26 \mathrm{E}-34$ & $3.80 \mathrm{E}-45$ \\
\hline-1.5 & -88.73 & 9.97E-09 & $1.00 \mathrm{E}+02$ & $3.57 \mathrm{E}-20$ & $3.58 \mathrm{E}-10$ & $2.45 \mathrm{E}-40$ & $2.46 \mathrm{E}-30$ & $1.26 \mathrm{E}-40$ & $1.26 \mathrm{E}-30$ & $3.80 \mathrm{E}-41$ \\
\hline-1 & -59.16 & $9.97 \mathrm{E}-09$ & $1.00 \mathrm{E}+02$ & $1.07 \mathrm{E}-16$ & $1.07 \mathrm{E}-06$ & $8.16 \mathrm{E}-36$ & $8.18 \mathrm{E}-26$ & $4.20 \mathrm{E}-36$ & $4.21 \mathrm{E}-26$ & $1.27 \mathrm{E}-36$ \\
\hline-0.5 & -29.58 & 9.97E-09 & $1.00 \mathrm{E}+02$ & $1.07 \mathrm{E}-13$ & $1.07 \mathrm{E}-03$ & $8.16 \mathrm{E}-31$ & $8.18 \mathrm{E}-21$ & $4.20 \mathrm{E}-31$ & $4.21 \mathrm{E}-21$ & $1.27 \mathrm{E}-31$ \\
\hline 0 & -0.095 & $2.86 \mathrm{E}-10$ & $2.87 \mathrm{E}+00$ & $3.06 \mathrm{E}-12$ & 3.07E-02 & $2.34 \mathrm{E}-27$ & $2.35 \mathrm{E}-17$ & $1.21 \mathrm{E}-27$ & $1.21 \mathrm{E}-17$ & $3.63 \mathrm{E}-28$ \\
\hline 0.5 & 29.58 & $2.83 \mathrm{E}-14$ & $2.84 \mathrm{E}-04$ & $4.51 \mathrm{E}-14$ & $4.52 \mathrm{E}-04$ & $1.67 \mathrm{E}-25$ & $1.68 \mathrm{E}-15$ & $8.49 \mathrm{E}-26$ & $8.52 \mathrm{E}-16$ & $2.51 \mathrm{E}-26$ \\
\hline 1 & 59.16 & $2.83 \mathrm{E}-18$ & $2.84 \mathrm{E}-08$ & $4.52 \mathrm{E}-18$ & $4.53 \mathrm{E}-08$ & $1.67 \mathrm{E}-21$ & $1.68 \mathrm{E}-11$ & $8.46 \mathrm{E}-22$ & $8.49 \mathrm{E}-12$ & $2.50 \mathrm{E}-22$ \\
\hline 1.5 & 88.73 & $2.01 \mathrm{E}-22$ & $2.02 \mathrm{E}-12$ & $3.26 \mathrm{E}-22$ & $3.27 \mathrm{E}-12$ & $1.16 \mathrm{E}-17$ & $1.16 \mathrm{E}-07$ & $5.88 \mathrm{E}-18$ & $5.90 \mathrm{E}-08$ & $1.74 \mathrm{E}-18$ \\
\hline 2 & 118.13 & $2.01 \mathrm{E}-29$ & $2.02 \mathrm{E}-19$ & $3.26 \mathrm{E}-29$ & $3.27 \mathrm{E}-19$ & $1.16 \mathrm{E}-16$ & $1.16 \mathrm{E}-06$ & $5.88 \mathrm{E}-17$ & $5.90 \mathrm{E}-07$ & $1.74 \mathrm{E}-17$ \\
\hline 2.5 & 147.89 & $2.01 \mathrm{E}-36$ & $2.02 \mathrm{E}-26$ & $3.26 \mathrm{E}-36$ & $3.27 \mathrm{E}-26$ & $1.16 \mathrm{E}-15$ & $1.16 \mathrm{E}-05$ & $5.88 \mathrm{E}-16$ & $5.90 \mathrm{E}-06$ & $1.74 \mathrm{E}-16$ \\
\hline 3 & 177.47 & $2.02 \mathrm{E}-43$ & $2.03 \mathrm{E}-33$ & $3.29 \mathrm{E}-43$ & $3.30 \mathrm{E}-33$ & $1.16 \mathrm{E}-14$ & $1.16 \mathrm{E}-04$ & $5.88 \mathrm{E}-15$ & $5.90 \mathrm{E}-05$ & $1.74 \mathrm{E}-15$ \\
\hline 3.5 & 207.05 & $2.02 \mathrm{E}-50$ & $2.03 \mathrm{E}-40$ & $3.31 \mathrm{E}-50$ & $3.32 \mathrm{E}-40$ & $1.16 \mathrm{E}-13$ & $1.16 \mathrm{E}-03$ & $5.88 \mathrm{E}-14$ & $5.90 \mathrm{E}-04$ & $1.74 \mathrm{E}-14$ \\
\hline 4 & 236.62 & $2.02 \mathrm{E}-57$ & $2.03 \mathrm{E}-47$ & $3.32 \mathrm{E}-57$ & $3.33 \mathrm{E}-47$ & 1.16E-12 & $1.16 \mathrm{E}-02$ & $5.87 \mathrm{E}-13$ & $5.89 \mathrm{E}-03$ & $1.74 \mathrm{E}-13$ \\
\hline 4.5 & 266.2 & $2.02 \mathrm{E}-64$ & $2.03 E-54$ & $3.31 \mathrm{E}-64$ & $3.32 E-54$ & $1.15 \mathrm{E}-11$ & $1.15 \mathrm{E}-01$ & $5.86 \mathrm{E}-12$ & $5.88 \mathrm{E}-02$ & $1.74 \mathrm{E}-12$ \\
\hline 5 & 295.78 & $1.99 \mathrm{E}-71$ & $2.00 \mathrm{E}-61$ & $3.26 \mathrm{E}-71$ & $3.27 \mathrm{E}-61$ & $1.13 \mathrm{E}-10$ & $1.13 \mathrm{E}+00$ & $5.76 \mathrm{E}-11$ & $5.78 \mathrm{E}-01$ & $1.71 \mathrm{E}-11$ \\
\hline 5.5 & 325.36 & $1.70 \mathrm{E}-78$ & $1.71 \mathrm{E}-68$ & $2.79 \mathrm{E}-78$ & $2.80 \mathrm{E}-68$ & $9.69 \mathrm{E}-10$ & $9.72 E+00$ & $4.93 \mathrm{E}-10$ & $4.94 \mathrm{E}+00$ & $1.46 \mathrm{E}-10$ \\
\hline 6.5 & 384.51 & $1.00 \mathrm{E}-93$ & $1.00 \mathrm{E}-83$ & $1.64 \mathrm{E}-93$ & $1.64 \mathrm{E}-83$ & 5.71E-09 & $5.73 \mathrm{E}+01$ & $2.90 \mathrm{E}-09$ & $2.91 \mathrm{E}+01$ & $8.60 \mathrm{E}-10$ \\
\hline 7 & 414.09 & $1.00-100$ & $0.00 \mathrm{E}+00$ & $1.00-100$ & $0.00 \mathrm{E}+00$ & $5.98 \mathrm{E}-09$ & $6.00 \mathrm{E}+01$ & $3.04 \mathrm{E}-09$ & $3.05 \mathrm{E}+01$ & $9.00 \mathrm{E}-10$ \\
\hline 7.5 & 443.67 & $1.00-100$ & $0.00 \mathrm{E}+00$ & $1.00-100$ & $0.00 \mathrm{E}+00$ & $6.01 \mathrm{E}-09$ & $6.03 \mathrm{E}+01$ & $3.05 \mathrm{E}-09$ & $3.06 \mathrm{E}+01$ & $9.04 \mathrm{E}-10$ \\
\hline 8 & 437.25 & $1.00-100$ & $0.00 \mathrm{E}+00$ & $1.00-100$ & $0.00 \mathrm{E}+00$ & $6.01 \mathrm{E}-09$ & $6.03 E+01$ & $3.05 \mathrm{E}-09$ & $3.06 \mathrm{E}+01$ & $9.05 \mathrm{E}-10$ \\
\hline 8.5 & 502.83 & $1.00-100$ & $0.00 \mathrm{E}+00$ & $1.00-100$ & $0.00 \mathrm{E}+00$ & $6.01 \mathrm{E}-09$ & $6.03 \mathrm{E}+01$ & $3.06 \mathrm{E}-09$ & $3.07 \mathrm{E}+01$ & $9.05 \mathrm{E}-10$ \\
\hline 9 & 532.4 & $1.00-100$ & $0.00 \mathrm{E}+00$ & $1.00-100$ & $0.00 \mathrm{E}+00$ & $6.01 \mathrm{E}-09$ & $6.03 E+01$ & $3.06 \mathrm{E}-09$ & $3.07 \mathrm{E}+01$ & $9.05 \mathrm{E}-10$ \\
\hline 9.5 & 561.98 & $1.00-100$ & $0.00 \mathrm{E}+00$ & $1.00-100$ & $0.00 \mathrm{E}+00$ & $6.01 \mathrm{E}-09$ & $6.03 \mathrm{E}+01$ & $3.06 \mathrm{E}-09$ & $3.07 \mathrm{E}+01$ & $9.05 \mathrm{E}-10$ \\
\hline 10 & 591.56 & $1.00-100$ & $0.00 \mathrm{E}+00$ & $1.00-100$ & $0.00 \mathrm{E}+00$ & $6.01 \mathrm{E}-09$ & $6.03 \mathrm{E}+01$ & $3.06 \mathrm{E}-09$ & $3.07 \mathrm{E}+01$ & $9.05 \mathrm{E}-10$ \\
\hline 10.5 & 621.14 & $1.00-100$ & $0.00 \mathrm{E}+00$ & $1.00-100$ & $0.00 \mathrm{E}+00$ & $6.01 \mathrm{E}-09$ & $6.03 E+01$ & $3.06 \mathrm{E}-09$ & $3.07 \mathrm{E}+01$ & $9.05 \mathrm{E}-10$ \\
\hline 11 & 650.72 & $1.00-100$ & $0.00 \mathrm{E}+00$ & $1.00-100$ & $0.00 \mathrm{E}+00$ & $6.01 \mathrm{E}-09$ & $6.03 \mathrm{E}+01$ & $3.06 \mathrm{E}-09$ & $3.07 \mathrm{E}+01$ & $9.05 \mathrm{E}-10$ \\
\hline 11.5 & 680.29 & $1.00-100$ & $0.00 \mathrm{E}+00$ & $1.00-100$ & $0.00 \mathrm{E}+00$ & $6.01 \mathrm{E}-09$ & $6.03 \mathrm{E}+01$ & $3.06 \mathrm{E}-09$ & $3.07 \mathrm{E}+01$ & $9.05 \mathrm{E}-10$ \\
\hline 12 & 709.87 & $1.00-100$ & $0.00 \mathrm{E}+00$ & $1.00-100$ & $0.00 \mathrm{E}+00$ & $6.01 \mathrm{E}-09$ & $6.03 \mathrm{E}+01$ & $3.06 \mathrm{E}-09$ & $3.07 \mathrm{E}+01$ & $9.05 \mathrm{E}-10$ \\
\hline 12.5 & 739.45 & $1.00-100$ & $0.00 \mathrm{E}+00$ & $1.00-100$ & $0.00 \mathrm{E}+00$ & $6.01 \mathrm{E}-09$ & $6.03 \mathrm{E}+01$ & $3.06 \mathrm{E}-09$ & $3.07 \mathrm{E}+01$ & $9.05 \mathrm{E}-10$ \\
\hline 13 & 769.03 & $1.00-100$ & $0.00 \mathrm{E}+00$ & $1.00-100$ & $0.00 \mathrm{E}+00$ & $6.01 \mathrm{E}-09$ & $6.03 E+01$ & $3.06 \mathrm{E}-09$ & $3.07 \mathrm{E}+01$ & $9.05 \mathrm{E}-10$ \\
\hline 13.5 & 798.6 & $1.00-100$ & $0.00 \mathrm{E}+00$ & $1.00-100$ & $0.00 \mathrm{E}+00$ & $6.01 \mathrm{E}-09$ & $6.03 \mathrm{E}+01$ & $3.06 \mathrm{E}-09$ & $3.07 \mathrm{E}+01$ & $9.05 \mathrm{E}-10$ \\
\hline
\end{tabular}


Table A1 (Continuation). Mercury Speciation at $\mathrm{pH}$ of 4 and Total Mercury Concentration of $0.002 \mathrm{mg} / \mathrm{L}$ (Data Used in Figure 2).

\begin{tabular}{|c|c|c|c|c|c|c|}
\hline $\mathrm{pE}$ & $\begin{array}{c}\text { Eh } \\
(\mathrm{mV})\end{array}$ & $\begin{array}{l}\text { Percent } \\
\mathrm{HgCl}_{4}{ }^{2-}\end{array}$ & $\begin{array}{c}\text { Conc. (M) } \\
\mathrm{Hg}(\mathrm{aq})\end{array}$ & $\begin{array}{l}\text { Percent } \\
\mathrm{Hg}(\mathrm{aq})\end{array}$ & $\begin{array}{c}\text { Conc. (M) } \\
\mathrm{HgS}(\mathrm{s})\end{array}$ & $\begin{array}{l}\text { Percent } \\
\mathrm{HgS}(\mathrm{s})\end{array}$ \\
\hline-2 & -200 & $3.81 \mathrm{E}-35$ & $2.15 \mathrm{E}-28$ & $2.16 \mathrm{E}-18$ & $0.00 \mathrm{E}+00$ & $0.00 \mathrm{E}+00$ \\
\hline-1.5 & -88.73 & $3.81 \mathrm{E}-31$ & $2.15 \mathrm{E}-25$ & $2.16 \mathrm{E}-15$ & $0.00 \mathrm{E}+00$ & $0.00 \mathrm{E}+00$ \\
\hline-1 & -59.16 & $1.27 \mathrm{E}-26$ & $7.18 \mathrm{E}-22$ & $7.20 \mathrm{E}-12$ & $0.00 \mathrm{E}+00$ & $0.00 \mathrm{E}+00$ \\
\hline-0.5 & -29.58 & $1.27 \mathrm{E}-21$ & $7.18 E-18$ & $7.20 \mathrm{E}-08$ & $0.00 \mathrm{E}+00$ & $0.00 \mathrm{E}+00$ \\
\hline 0 & -0.095 & $3.64 \mathrm{E}-18$ & $2.06 \mathrm{E}-15$ & 2.07E-05 & $9.68 \mathrm{E}-09$ & $9.71 E+01$ \\
\hline 0.5 & 29.58 & $2.52 \mathrm{E}-16$ & $1.44 \mathrm{E}-14$ & $1.44 \mathrm{E}-04$ & $9.97 \mathrm{E}-09$ & $1.00 \mathrm{E}+02$ \\
\hline 1 & 59.16 & $2.51 \mathrm{E}-12$ & $1.44 \mathrm{E}-11$ & $1.44 \mathrm{E}-01$ & $9.96 \mathrm{E}-09$ & $9.99 E+01$ \\
\hline 1.5 & 88.73 & $1.75 \mathrm{E}-08$ & 9.97E-09 & $1.00 \mathrm{E}+02$ & $0.00 \mathrm{E}+00$ & $0.00 \mathrm{E}+00$ \\
\hline 2 & 118.13 & $1.75 \mathrm{E}-07$ & 9.97E-09 & $1.00 \mathrm{E}+02$ & $0.00 \mathrm{E}+00$ & $0.00 \mathrm{E}+00$ \\
\hline 2.5 & 147.89 & $1.75 \mathrm{E}-06$ & 9.97E-09 & $1.00 \mathrm{E}+02$ & $0.00 \mathrm{E}+00$ & $0.00 \mathrm{E}+00$ \\
\hline 3 & 177.47 & $1.75 \mathrm{E}-05$ & $9.97 \mathrm{E}-09$ & $1.00 \mathrm{E}+02$ & $0.00 \mathrm{E}+00$ & $0.00 \mathrm{E}+00$ \\
\hline 3.5 & 207.05 & $1.75 \mathrm{E}-04$ & 9.97E-09 & $1.00 \mathrm{E}+02$ & $0.00 \mathrm{E}+00$ & $0.00 \mathrm{E}+00$ \\
\hline 4 & 236.62 & $1.75 \mathrm{E}-03$ & 9.97E-09 & $1.00 \mathrm{E}+02$ & $0.00 \mathrm{E}+00$ & $0.00 \mathrm{E}+00$ \\
\hline 4.5 & 266.2 & 1.75E-02 & $9.95 \mathrm{E}-09$ & $9.98 \mathrm{E}+01$ & $0.00 \mathrm{E}+00$ & $0.00 \mathrm{E}+00$ \\
\hline 5 & 295.78 & $1.72 \mathrm{E}-01$ & $9.78 \mathrm{E}-09$ & $9.81 \mathrm{E}+01$ & $0.00 \mathrm{E}+00$ & $0.00 \mathrm{E}+00$ \\
\hline 5.5 & 325.36 & $1.46 \mathrm{E}+00$ & $8.36 \mathrm{E}-09$ & $8.39 \mathrm{E}+01$ & $0.00 \mathrm{E}+00$ & $0.00 \mathrm{E}+00$ \\
\hline 6 & 354.94 & $5.97 \mathrm{E}+00$ & $3.41 E-09$ & $3.42 \mathrm{E}+01$ & $0.00 \mathrm{E}+00$ & $0.00 \mathrm{E}+00$ \\
\hline 6.5 & 384.51 & $8.63 E+00$ & $4.93 \mathrm{E}-10$ & $4.94 \mathrm{E}+00$ & $0.00 \mathrm{E}+00$ & $0.00 \mathrm{E}+00$ \\
\hline 7 & 414.09 & $9.03 E+00$ & $5.16 \mathrm{E}-11$ & $5.18 \mathrm{E}-01$ & $0.00 \mathrm{E}+00$ & $0.00 \mathrm{E}+00$ \\
\hline 7.5 & 443.67 & $9.07 E+00$ & $5.18 \mathrm{E}-12$ & $5.20 \mathrm{E}-02$ & $0.00 \mathrm{E}+00$ & $0.00 \mathrm{E}+00$ \\
\hline 8 & 437.25 & $9.08 \mathrm{E}+00$ & $5.18 \mathrm{E}-13$ & $5.20 \mathrm{E}-03$ & $0.00 \mathrm{E}+00$ & $0.00 \mathrm{E}+00$ \\
\hline 8.5 & 502.83 & $9.08 \mathrm{E}+00$ & $5.18 \mathrm{E}-14$ & $5.20 \mathrm{E}-04$ & $0.00 \mathrm{E}+00$ & $0.00 \mathrm{E}+00$ \\
\hline 9 & 532.4 & $9.08 \mathrm{E}+00$ & $5.18 \mathrm{E}-15$ & $5.20 \mathrm{E}-05$ & $0.00 \mathrm{E}+00$ & $0.00 \mathrm{E}+00$ \\
\hline 9.5 & 561.98 & $9.08 \mathrm{E}+00$ & $5.18 \mathrm{E}-16$ & $5.20 \mathrm{E}-06$ & $0.00 \mathrm{E}+00$ & $0.00 \mathrm{E}+00$ \\
\hline 10 & 591.56 & $9.08 \mathrm{E}+00$ & $5.18 \mathrm{E}-17$ & $5.20 \mathrm{E}-07$ & $0.00 \mathrm{E}+00$ & $0.00 \mathrm{E}+00$ \\
\hline 10.5 & 621.14 & $9.08 \mathrm{E}+00$ & $5.18 \mathrm{E}-18$ & $5.20 \mathrm{E}-08$ & $0.00 \mathrm{E}+00$ & $0.00 \mathrm{E}+00$ \\
\hline 11 & 650.72 & $9.08 E+00$ & $5.18 \mathrm{E}-19$ & 5.20E-09 & $0.00 \mathrm{E}+00$ & $0.00 \mathrm{E}+00$ \\
\hline 11.5 & 680.29 & $9.08 E+00$ & $5.18 \mathrm{E}-20$ & $5.20 \mathrm{E}-10$ & $0.00 \mathrm{E}+00$ & $0.00 \mathrm{E}+00$ \\
\hline 12 & 709.87 & $9.08 \mathrm{E}+00$ & $5.18 \mathrm{E}-21$ & $5.20 \mathrm{E}-11$ & $0.00 \mathrm{E}+00$ & $0.00 \mathrm{E}+00$ \\
\hline 12.5 & 739.45 & $9.08 \mathrm{E}+00$ & $5.18 \mathrm{E}-22$ & $5.20 \mathrm{E}-12$ & $0.00 \mathrm{E}+00$ & $0.00 \mathrm{E}+00$ \\
\hline 13 & 769.03 & $9.08 \mathrm{E}+00$ & $5.18 \mathrm{E}-23$ & $5.20 \mathrm{E}-13$ & $0.00 E+00$ & $0.00 \mathrm{E}+00$ \\
\hline 13.5 & 798.6 & $9.08 \mathrm{E}+00$ & $5.18 \mathrm{E}-24$ & $5.20 \mathrm{E}-14$ & $0.00 \mathrm{E}+00$ & $0.00 \mathrm{E}+00$ \\
\hline
\end{tabular}


Table A2. Mercury Speciation at pH of 4 and Total Mercury Concentration of $0.2 \mathrm{mg} / \mathrm{L}$ (Data Used in Figure 3).

\begin{tabular}{|c|c|c|c|c|c|c|c|c|c|c|}
\hline $\mathrm{pE}$ & $\begin{array}{c}\text { Eh } \\
(\mathrm{mV})\end{array}$ & $\begin{array}{l}\text { Conc. (M) } \\
\mathrm{Hg}(\mathrm{CH} 3) \mathrm{S}-\end{array}$ & $\begin{array}{c}\text { Percent } \\
\mathrm{Hg}(\mathrm{CH} 3) \mathrm{S}-\end{array}$ & $\begin{array}{l}\text { Conc. (M) } \\
\mathrm{Hg}(\mathrm{HS}) 2\end{array}$ & $\begin{array}{c}\text { Percent } \\
\mathrm{Hg}(\mathrm{HS}) 3\end{array}$ & $\begin{array}{l}\text { Conc. (M) } \\
\mathrm{HgCl} 2 \text { (aq) }\end{array}$ & $\begin{array}{c}\text { Percent } \\
\mathrm{HgCl} 2(\mathrm{aq})\end{array}$ & $\begin{array}{c}\text { Conc. (M) } \\
\mathrm{HgCl} 3-\end{array}$ & $\begin{array}{l}\text { Percent } \\
\mathrm{HgCl3}-\end{array}$ & $\begin{array}{c}\text { Conc. (M) } \\
\mathrm{HgCl} 42-\end{array}$ \\
\hline-2 & -200 & $1.00 \mathrm{E}-06$ & $1.00 \mathrm{E}+02$ & $3.58 \mathrm{E}-22$ & $3.58 \mathrm{E}-14$ & $2.45 \mathrm{E}-42$ & $2.45 \mathrm{E}-34$ & $1.26 \mathrm{E}-42$ & $1.26 \mathrm{E}-34$ & $3.81 \mathrm{E}-43$ \\
\hline-1.5 & -88.73 & $1.00 \mathrm{E}-06$ & $1.00 \mathrm{E}+02$ & $3.58 \mathrm{E}-18$ & $3.58 \mathrm{E}-10$ & $2.45 \mathrm{E}-38$ & $2.45 \mathrm{E}-30$ & $1.26 \mathrm{E}-38$ & $1.26 \mathrm{E}-30$ & $3.81 E-39$ \\
\hline-1 & -59.16 & $1.00 \mathrm{E}-06$ & $1.00 \mathrm{E}+02$ & $1.07 \mathrm{E}-14$ & $1.07 \mathrm{E}-06$ & $8.19 \mathrm{E}-34$ & 8.19E-26. & $4.22 \mathrm{E}-34$ & $4.22 \mathrm{E}-26$ & $1.27 \mathrm{E}-34$ \\
\hline-0.5 & -29.58 & $1.00 \mathrm{E}-06$ & $1.00 \mathrm{E}+02$ & $1.07 \mathrm{E}-11$ & $1.07 \mathrm{E}-03$ & $8.19 \mathrm{E}-29$ & $8.19 \mathrm{E}-21$ & $4.22 \mathrm{E}-29$ & $4.22 \mathrm{E}-21$ & $1.27 \mathrm{E}-29$ \\
\hline 0 & -0.095 & $2.86 \mathrm{E}-10$ & $2.86 \mathrm{E}-02$ & $3.06 \mathrm{E}-12$ & $3.06 \mathrm{E}-04$ & $2.34 \mathrm{E}-27$ & $2.34 \mathrm{E}-19$ & $1.21 \mathrm{E}-27$ & $1.21 \mathrm{E}-19$ & $3.63 \mathrm{E}-28$ \\
\hline 0.5 & 29.58 & $2.83 \mathrm{E}-14$ & $2.83 \mathrm{E}-06$ & $4.51 \mathrm{E}-14$ & $4.51 \mathrm{E}-06$ & $1.67 \mathrm{E}-25$ & $1.67 \mathrm{E}-17$ & $8.49 \mathrm{E}-26$ & $8.49 \mathrm{E}-18$ & $2.51 \mathrm{E}-26$ \\
\hline 1 & 59.16 & $2.83 \mathrm{E}-18$ & $2.83 \mathrm{E}-10$ & $4.52 \mathrm{E}-18$ & $4.52 \mathrm{E}-10$ & $1.67 \mathrm{E}-21$ & $1.67 \mathrm{E}-13$ & $8.46 \mathrm{E}-22$ & $8.46 \mathrm{E}-14$ & $2.50 \mathrm{E}-22$ \\
\hline 1.5 & 88.73 & $2.83 \mathrm{E}-22$ & $2.83 \mathrm{E}-14$ & $4.60 \mathrm{E}-22$ & $4.60 \mathrm{E}-14$ & $1.63 \mathrm{E}-17$ & $1.63 \mathrm{E}-09$ & $8.29 \mathrm{E}-18$ & $8.29 \mathrm{E}-10$ & $2.45 E-18$ \\
\hline 2 & 118.13 & $5.66 \mathrm{E}-28$ & $5.66 \mathrm{E}-20$ & $9.20 \mathrm{E}-28$ & $9.20 \mathrm{E}-20$ & $3.26 \mathrm{E}-15$ & $3.26 \mathrm{E}-07$ & $1.66 \mathrm{E}-15$ & $1.66 \mathrm{E}-07$ & $4.91 \mathrm{E}-16$ \\
\hline 2.5 & 147.89 & $5.66 \mathrm{E}-35$ & $5.66 \mathrm{E}-27$ & $9.20 \mathrm{E}-35$ & $9.20 \mathrm{E}-27$ & $3.26 \mathrm{E}-14$ & $3.26 \mathrm{E}-06$ & $1.66 \mathrm{E}-14$ & $1.66 \mathrm{E}-06$ & $4.91 \mathrm{E}-15$ \\
\hline 3 & 177.47 & $5.69 \mathrm{E}-42$ & $5.69 \mathrm{E}-34$ & $9.29 \mathrm{E}-42$ & $9.29 \mathrm{E}-34$ & $3.26 \mathrm{E}-13$ & $3.26 \mathrm{E}-05$ & $1.66 \mathrm{E}-13$ & $1.66 \mathrm{E}-05$ & $4.91 \mathrm{E}-14$ \\
\hline 3.5 & 207.05 & $5.70 E-49$ & $5.70 \mathrm{E}-41$ & $9.34 \mathrm{E}-49$ & $9.34 \mathrm{E}-41$ & $3.26 \mathrm{E}-12$ & $3.26 \mathrm{E}-04$ & $1.66 \mathrm{E}-12$ & $1.66 \mathrm{E}-04$ & $4.91 \mathrm{E}-13$ \\
\hline 4 & 236.62 & $5.71 \mathrm{E}-56$ & $5.71 \mathrm{E}-48$ & $9.36 \mathrm{E}-56$ & $9.36 \mathrm{E}-48$ & $3.26 \mathrm{E}-11$ & $3.26 \mathrm{E}-03$ & $1.66 \mathrm{E}-11$ & $1.66 \mathrm{E}-03$ & $4.91 \mathrm{E}-12$ \\
\hline 4.5 & 266.2 & $5.71 \mathrm{E}-63$ & $5.71 \mathrm{E}-55$ & $9.36 \mathrm{E}-63$ & $9.36 \mathrm{E}-55$ & $3.26 \mathrm{E}-10$ & $3.26 \mathrm{E}-02$ & $1.66 \mathrm{E}-10$ & $1.66 \mathrm{E}-02$ & $4.91 \mathrm{E}-11$ \\
\hline 5 & 295.78 & $5.71 \mathrm{E}-70$ & $5.71 \mathrm{E}-62$ & 9.37E-70 & 9.37E-62 & $3.26 \mathrm{E}-09$ & $3.26 \mathrm{E}-01$ & $1.66 \mathrm{E}-09$ & $1.66 \mathrm{E}-01$ & $4.91 \mathrm{E}-10$ \\
\hline 5.5 & 325.36 & $5.71 \mathrm{E}-77$ & $5.71 \mathrm{E}-69$ & $9.37 \mathrm{E}-77$ & 9.37E-69 & $3.26 \mathrm{E}-08$ & $3.26 \mathrm{E}+00$ & $1.66 \mathrm{E}-08$ & $1.66 \mathrm{E}+00$ & $4.91 \mathrm{E}-09$ \\
\hline 6 & 354.94 & $4.53 \mathrm{E}-84$ & $4.53 \mathrm{E}-76$ & $7.43 \mathrm{E}-84$ & $7.43 \mathrm{E}-76$ & $2.59 \mathrm{E}-07$ & $2.59 \mathrm{E}+01$ & $1.31 \mathrm{E}-07$ & $1.31 \mathrm{E}+01$ & $3.89 \mathrm{E}-08$ \\
\hline 6.5 & 384.51 & $1.00 \mathrm{E}-91$ & $1.00 \mathrm{E}-83$ & $1.65 E-91$ & $1.65 E-83$ & $5.73 \mathrm{E}-07$ & $5.73 \mathrm{E}+01$ & $2.91 \mathrm{E}-07$ & $2.91 \mathrm{E}+01$ & $8.63 \mathrm{E}-08$ \\
\hline 7 & 414.09 & $1.05 \mathrm{E}-99$ & $1.05 \mathrm{E}-91$ & $1.72 \mathrm{E}-99$ & $1.72 \mathrm{E}-91$ & $6.00 \mathrm{E}-07$ & $6.00 \mathrm{E}+01$ & 3.05E-07 & $3.05 \mathrm{E}+01$ & $9.03 \mathrm{E}-08$ \\
\hline 7.5 & 443.67 & $1.00-100$ & $0.00 \mathrm{E}+00$ & $1.00-100$ & $0.00 \mathrm{E}+00$ & $6.02 E-07$ & $6.02 E+01$ & $3.06 \mathrm{E}-07$ & $3.06 \mathrm{E}+01$ & $9.07 \mathrm{E}-08$ \\
\hline 8 & 437.25 & $1.00-100$ & $0.00 \mathrm{E}+00$ & $1.00-100$ & $0.00 \mathrm{E}+00$ & $6.03 \mathrm{E}-07$ & $6.03 E+01$ & $3.06 \mathrm{E}-07$ & $3.06 \mathrm{E}+01$ & $9.07 \mathrm{E}-08$ \\
\hline 8.5 & 502.83 & $1.00-100$ & $0.00 \mathrm{E}+00$ & $1.00-100$ & $0.00 \mathrm{E}+00$ & $6.03 \mathrm{E}-07$ & $6.03 \mathrm{E}+01$ & $3.06 \mathrm{E}-07$ & $3.06 \mathrm{E}+01$ & $9.08 \mathrm{E}-08$ \\
\hline 9 & 532.4 & $1.00-100$ & $0.00 \mathrm{E}+00$ & $1.00-100$ & $0.00 \mathrm{E}+00$ & $6.03 \mathrm{E}-07$ & $6.03 E+01$ & $3.06 \mathrm{E}-07$ & $3.06 \mathrm{E}+01$ & $9.08 \mathrm{E}-08$ \\
\hline 9.5 & 561.98 & $1.00-100$ & $0.00 \mathrm{E}+00$ & $1.00-100$ & $0.00 \mathrm{E}+00$ & $6.03 \mathrm{E}-07$ & $6.03 E+01$ & $3.06 \mathrm{E}-07$ & $3.06 \mathrm{E}+01$ & $9.08 \mathrm{E}-08$ \\
\hline 10 & 591.56 & $1.00-100$ & $0.00 E+00$ & $1.00-100$ & $0.00 \mathrm{E}+00$ & $6.03 \mathrm{E}-07$ & $6.03 E+01$ & $3.06 \mathrm{E}-07$ & $3.06 \mathrm{E}+01$ & $9.08 \mathrm{E}-08$ \\
\hline 10.5 & 621.14 & $1.00-100$ & $0.00 \mathrm{E}+00$ & $1.00-100$ & $0.00 \mathrm{E}+00$ & $6.03 \mathrm{E}-07$ & $6.03 \mathrm{E}+01$ & $3.06 \mathrm{E}-07$ & $3.06 \mathrm{E}+01$ & $9.08 \mathrm{E}-08$ \\
\hline 11 & 650.72 & $1.00-100$ & $0.00 \mathrm{E}+00$ & $1.00-100$ & $0.00 \mathrm{E}+00$ & $6.03 \mathrm{E}-07$ & $6.03 E+01$ & $3.06 \mathrm{E}-07$ & $3.06 \mathrm{E}+01$ & $9.08 \mathrm{E}-08$ \\
\hline 11.5 & 680.29 & $1.00-100$ & $0.00 \mathrm{E}+00$ & $1.00-100$ & $0.00 \mathrm{E}+00$ & $6.03 E-07$ & $6.03 E+01$ & $3.06 \mathrm{E}-07$ & $3.06 \mathrm{E}+01$ & $9.08 \mathrm{E}-08$ \\
\hline 12 & 709.87 & $1.00-100$ & $0.00 \mathrm{E}+00$ & $1.00-100$ & $0.00 \mathrm{E}+00$ & $6.03 \mathrm{E}-07$ & $6.03 E+01$ & $3.06 \mathrm{E}-07$ & $3.06 \mathrm{E}+01$ & $9.08 \mathrm{E}-08$ \\
\hline 12.5 & 739.45 & $1.00-100$ & $0.00 \mathrm{E}+00$ & $1.00-100$ & $0.00 \mathrm{E}+00$ & $6.03 \mathrm{E}-07$ & $6.03 E+01$ & $3.06 \mathrm{E}-07$ & $3.06 \mathrm{E}+01$ & $9.08 \mathrm{E}-08$ \\
\hline 13 & 769.03 & $1.00-100$ & $0.00 \mathrm{E}+00$ & $1.00-100$ & $0.00 \mathrm{E}+00$ & $6.03 \mathrm{E}-07$ & $6.03 E+01$ & $3.06 \mathrm{E}-07$ & $3.06 \mathrm{E}+01$ & $9.08 \mathrm{E}-08$ \\
\hline 13.5 & 798.6 & $1.00-100$ & $0.00 \mathrm{E}+00$ & $1.00-100$ & $0.00 \mathrm{E}+00$ & $6.03 \mathrm{E}-07$ & $6.03 E+01$ & $3.06 \mathrm{E}-07$ & $3.06 \mathrm{E}+01$ & $9.08 \mathrm{E}-08$ \\
\hline
\end{tabular}


Table A2 (Continuation). Mercury Speciation at pH of 4 and Total Mercury Concentration of $0.2 \mathrm{mg} / \mathrm{L}$ (Data Used in Figure 3).

\begin{tabular}{|c|c|c|c|c|c|c|c|c|}
\hline $\mathrm{pE}$ & $\begin{array}{c}\text { Eh } \\
(\mathrm{mV})\end{array}$ & $\begin{array}{c}\text { Percent } \\
\mathrm{HgCl} 42- \\
\end{array}$ & $\begin{array}{c}\text { Conc. (M) } \\
\mathrm{Hg}(\mathrm{aq})\end{array}$ & $\begin{array}{l}\text { Percent } \\
\mathrm{Hg}(\mathrm{aq})\end{array}$ & $\begin{array}{c}\text { Conc. (M) } \\
\mathrm{HgS}(\mathrm{s})\end{array}$ & $\begin{array}{l}\text { Percent } \\
\mathrm{HgS}(\mathrm{s})\end{array}$ & $\begin{array}{c}\text { Conc. (M) } \\
\mathrm{Hg}(\mathrm{s})\end{array}$ & $\begin{array}{c}\text { Percent } \\
\mathrm{Hg}(\mathrm{s})\end{array}$ \\
\hline-2 & -200 & 3.81 E-35 & $2.16 \mathrm{E}-26$ & $2.16 \mathrm{E}-18$ & $0.00 \mathrm{E}+00$ & $0.00 \mathrm{E}+00$ & $0.00 \mathrm{E}+00$ & $0.00 E+00$ \\
\hline-1.5 & -88.73 & $3.81 \mathrm{E}-31$ & $2.16 \mathrm{E}-23$ & $2.16 \mathrm{E}-15$ & $0.00 \mathrm{E}+00$ & $0.00 \mathrm{E}+00$ & $0.00 \mathrm{E}+00$ & $0.00 \mathrm{E}+00$ \\
\hline-1 & -59.16 & $1.27 \mathrm{E}-26$ & $7.20 \mathrm{E}-20$ & $7.20 \mathrm{E}-12$ & $0.00 \mathrm{E}+00$ & $0.00 \mathrm{E}+00$ & $0.00 \mathrm{E}+00$ & $0.00 \mathrm{E}+00$ \\
\hline-0.5 & -29.58 & $1.27 \mathrm{E}-21$ & $7.20 \mathrm{E}-16$ & $7.20 \mathrm{E}-08$ & $0.00 \mathrm{E}+00$ & $0.00 \mathrm{E}+00$ & $0.00 \mathrm{E}+00$ & $0.00 \mathrm{E}+00$ \\
\hline 0 & -0.095 & $3.63 \mathrm{E}-20$ & $2.06 \mathrm{E}-15$ & $2.06 \mathrm{E}-07$ & $1.00 \mathrm{E}-06$ & $1.00 \mathrm{E}+02$ & $0.00 \mathrm{E}+00$ & $0.00 \mathrm{E}+00$ \\
\hline 0.5 & 29.58 & $2.51 \mathrm{E}-18$ & $1.44 \mathrm{E}-14$ & $1.44 \mathrm{E}-06$ & $1.00 \mathrm{E}-06$ & $1.00 \mathrm{E}+02$ & $0.00 \mathrm{E}+00$ & $0.00 \mathrm{E}+00$ \\
\hline 1 & 59.16 & $2.50 \mathrm{E}-14$ & $1.44 \mathrm{E}-11$ & $1.44 \mathrm{E}-03$ & $1.00 \mathrm{E}-06$ & $1.00 \mathrm{E}+02$ & $0.00 \mathrm{E}+00$ & $0.00 \mathrm{E}+00$ \\
\hline 1.5 & 88.73 & $2.45 \mathrm{E}-10$ & $1.41 \mathrm{E}-08$ & $1.41 \mathrm{E}+00$ & $9.86 \mathrm{E}-07$ & $9.86 \mathrm{E}+01$ & $0.00 \mathrm{E}+00$ & $0.00 \mathrm{E}+00$ \\
\hline 2 & 118.13 & $4.91 \mathrm{E}-08$ & 2.81E-07 & $2.81 \mathrm{E}+01$ & $0.00 \mathrm{E}+00$ & $0.00 \mathrm{E}+00$ & $3.59 \mathrm{E}-07$ & $7.18 \mathrm{E}+01$ \\
\hline 2.5 & 147.89 & $4.91 \mathrm{E}-07$ & 2.81E-07 & $2.81 \mathrm{E}+01$ & $0.00 \mathrm{E}+00$ & $0.00 \mathrm{E}+00$ & $3.59 \mathrm{E}-07$ & $7.18 \mathrm{E}+01$ \\
\hline 3 & $177: 47$ & $4.91 \mathrm{E}-06$ & $2.81 \mathrm{E}-07$ & $2.81 \mathrm{E}+01$ & $0.00 \mathrm{E}+00$ & $0.00 \mathrm{E}+00$ & $3.59 \mathrm{E}-07$ & $7.18 \mathrm{E}+01$ \\
\hline 3.5 & 207.05 & $4.91 \mathrm{E}-05$ & $2.81 E-07$ & $2.81 \mathrm{E}+01$ & $0.00 \mathrm{E}+00$ & $0.00 \mathrm{E}+00$ & $3.59 \mathrm{E}-07$ & $7.18 \mathrm{E}+01$ \\
\hline 4 & 236.62 & $4.91 \mathrm{E}-04$ & 2.81E-07 & $2.81 \mathrm{E}+01$ & $0.00 \mathrm{E}+00$ & $0.00 \mathrm{E}+00$ & $3.59 \mathrm{E}-07$ & $7.18 \mathrm{E}+01$ \\
\hline 4.5 & 266.2 & $4.91 \mathrm{E}-03$ & $2.81 \mathrm{E}-07$ & $2.81 E+01$ & $0.00 \mathrm{E}+00$ & $0.00 \mathrm{E}+00$ & $3.59 \mathrm{E}-07$ & $7.18 E+01$ \\
\hline 5 & 295.78 & $4.91 \mathrm{E}-02$ & 2.81E-07 & $2.81 \mathrm{E}+01$ & $0.00 \mathrm{E}+00$ & $0.00 \mathrm{E}+00$ & $3.57 \mathrm{E}-07$ & $7.14 \mathrm{E}+01$ \\
\hline 5.5 & 325.36 & $4.91 \mathrm{E}-01$ & 2.81E-07 & $2.81 \mathrm{E}+01$ & $0.00 \mathrm{E}+00$ & $0.00 \mathrm{E}+00$ & $3.32 \mathrm{E}-07$ & $6.64 \mathrm{E}+01$ \\
\hline 6 & 354.94 & $3.89 \mathrm{E}+00$ & 2.23E-07 & $2.23 \mathrm{E}+01$ & $0.00 \mathrm{E}+00$ & $0.00 \mathrm{E}+00$ & $1.74 \mathrm{E}-07$ & $3.48 \mathrm{E}+01$ \\
\hline 6.5 & 384.51 & $8.63 \mathrm{E}+00$ & 4.94E-08 & $4.94 \mathrm{E}+00$ & $0.00 \mathrm{E}+00$ & $0.00 \mathrm{E}+00$ & $0.00 \mathrm{E}+00$ & $0.00 \mathrm{E}+00$ \\
\hline 7 & 414.09 & $9.03 E+00$ & 5.17E-09 & $5.17 \mathrm{E}-01$ & $0.00 \mathrm{E}+00$ & $0.00 \mathrm{E}+00$ & $0.00 \mathrm{E}+00$ & $0.00 E+00$ \\
\hline 7.5 & 443.67 & $9.07 \mathrm{E}+00$ & $5.20 \mathrm{E}-10$ & $5.20 \mathrm{E}-02$ & $0.00 \mathrm{E}+00$ & $0.00 \mathrm{E}+00$ & $0.00 \mathrm{E}+00$ & $0.00 \mathrm{E}+00$ \\
\hline 8 & 437.25 & $9.07 \mathrm{E}+00$ & $5.20 \mathrm{E}-11$ & $5.20 \mathrm{E}-03$ & $0.00 \mathrm{E}+00$ & $0.00 \mathrm{E}+00$ & $0.00 \mathrm{E}+00$ & $0.00 \mathrm{E}+00$ \\
\hline 8.5 & 502.83 & $9.08 \mathrm{E}+00$ & $5.20 \mathrm{E}-12$ & $5.20 \mathrm{E}-04$ & $0.00 \mathrm{E}+00$ & $0.00 \mathrm{E}+00$ & $0.00 \mathrm{E}+00$ & $0.00 \mathrm{E}+00$ \\
\hline 9 & 532.4 & $9.08 \mathrm{E}+00$ & $5.20 \mathrm{E}-13$ & $5.20 \mathrm{E}-05$ & $0.00 \mathrm{E}+00$ & $0.00 \mathrm{E}+00$ & $0.00 \mathrm{E}+00$ & $0.00 \mathrm{E}+00$ \\
\hline 9.5 & 561.98 & $9.08 E+00$ & $5.20 \mathrm{E}-14$ & $5.20 \mathrm{E}-06$ & $0.00 \mathrm{E}+00$ & $0.00 \mathrm{E}+00$ & $0.00 \mathrm{E}+00$ & $0.00 \mathrm{E}+00$ \\
\hline 10 & 591.56 & $9.08 \mathrm{E}+00$ & $5.20 \mathrm{E}-15$ & $5.20 \mathrm{E}-07$ & $0.00 \mathrm{E}+00$ & $0.00 \mathrm{E}+00$ & $0.00 \mathrm{E}+00$ & $0.00 \mathrm{E}+00$ \\
\hline 10.5 & 621.14 & $9.08 \mathrm{E}+00$ & $5.20 \mathrm{E}-16$ & $5.20 \mathrm{E}-08$ & $0.00 \mathrm{E}+00$ & $0.00 \mathrm{E}+00$ & $0.00 \mathrm{E}+00$ & $0.00 \mathrm{E}+00$ \\
\hline 11 & 650.72 & $9.08 \mathrm{E}+00$ & $5.20 \mathrm{E}-17$ & $5.20 \mathrm{E}-09$ & $0.00 \mathrm{E}+00$ & $0.00 \mathrm{E}+00$ & $0.00 \mathrm{E}+00$ & $0.00 \mathrm{E}+00$ \\
\hline 11.5 & 680.29 & $9.08 \mathrm{E}+00$ & $5.20 \mathrm{E}-18$ & $5.20 \mathrm{E}-10$ & $0.00 \mathrm{E}+00$ & $0.00 \mathrm{E}+00$ & $0.00 \mathrm{E}+00$ & $0.00 \mathrm{E}+00$ \\
\hline 12 & 709.87 & $9.08 \mathrm{E}+00$ & $5.20 \mathrm{E}-19$ & $5.20 \mathrm{E}-11$ & $0.00 \mathrm{E}+00$ & $0.00 \mathrm{E}+00$ & $0.00 \mathrm{E}+00$ & $0.00 \mathrm{E}+00$ \\
\hline 12.5 & 739.45 & $9.08 \mathrm{E}+00$ & $5.20 \mathrm{E}-20$ & $5.20 \mathrm{E}-12$ & $0.00 \mathrm{E}+00$ & $0.00 \mathrm{E}+00$ & $0.00 \mathrm{E}+00$ & $0.00 \mathrm{E}+00$ \\
\hline 13 & 769.03 & $9.08 E+00$ & $5.20 \mathrm{E}-21$ & $5.20 \mathrm{E}-13$ & $0.00 \mathrm{E}+00$ & $0.00 \mathrm{E}+00$ & $0.00 \mathrm{E}+00$ & $0.00 \mathrm{E}+00$ \\
\hline 13.5 & 798.6 & $9.08 \mathrm{E}+00$ & $5.20 \mathrm{E}-22$ & $5.20 \mathrm{E}-14$ & $0.00 \mathrm{E}+00$ & $0.00 \mathrm{E}+00$ & $0.00 \mathrm{E}+00$ & $0.00 \mathrm{E}+00$ \\
\hline
\end{tabular}


Table A3. Mercury Speciation at $\mathrm{pH}$ of 7 and Total Mercury Concentration of $0.002 \mathrm{mg} / \mathrm{L}$ (Data Used in Figure 4).

\begin{tabular}{|c|c|c|c|c|c|c|c|}
\hline $\mathrm{pE}$ & $\begin{array}{c}\mathrm{Eh} \\
(\mathrm{mV})\end{array}$ & $\begin{array}{l}\text { Conc. (M) } \\
\mathrm{Hg}\left(\mathrm{CH}_{3}\right) \mathrm{S}^{-}\end{array}$ & $\begin{array}{c}\text { Percent } \\
\mathrm{Hg}\left(\mathrm{CH}_{3}\right) \mathrm{S}^{-}\end{array}$ & $\begin{array}{l}\text { Conc. (M) } \\
\mathrm{Hg}(\mathrm{HS})_{2}\end{array}$ & $\begin{array}{l}\text { Percent } \\
\mathrm{Hg}(\mathrm{HS})_{3}\end{array}$ & $\begin{array}{l}\text { Conc. (M) } \\
\mathrm{hgCl}_{2} \text { (aq) }\end{array}$ & $\begin{array}{c}\text { Percent } \\
\mathrm{hgCl}_{2}(\mathrm{aq})\end{array}$ \\
\hline-2 & -200 & $2.04 \mathrm{E}-18$ & 2.05E-08 & $0.00 \mathrm{E}+00$ & $3.61 E+06$ & $1.16 \mathrm{E}-24$ & $1.16 \mathrm{E}-14$ \\
\hline-1.5 & -88.73 & $2.04 \mathrm{E}-25$ & $2.05 E-15$ & $0.00 \mathrm{E}+00$ & $3.61 \mathrm{E}+06$ & $1.16 \mathrm{E}-23$ & $1.16 \mathrm{E}-13$ \\
\hline-1 & -59.16 & $2.04 \mathrm{E}-32$ & $2.05 \mathrm{E}-22$ & $0.00 \mathrm{E}+00$ & $3.61 E+06$ & $1.16 \mathrm{E}-22$ & $1.16 \mathrm{E}-12$ \\
\hline-0.5 & -29.58 & $2.04 \mathrm{E}-39$ & $2.05 \mathrm{E}-29$ & $0.00 \mathrm{E}+00$ & $3.61 E+06$ & $1.16 \mathrm{E}-21$ & $1.16 \mathrm{E}-11$ \\
\hline 0 & -0.095 & $2.04 \mathrm{E}-46$ & $2.05 \mathrm{E}-36$ & $0.00 \mathrm{E}+00$ & $3.61 \mathrm{E}+06$ & $1.16 \mathrm{E}-20$ & $1.16 \mathrm{E}-10$ \\
\hline 0.5 & 29.58 & $2.04 \mathrm{E}-53$ & $2.05 E-43$ & $0.00 \mathrm{E}+00$ & $3.61 \mathrm{E}+06$ & $1.16 \mathrm{E}-19$ & $1.16 \mathrm{E}-09$ \\
\hline 1 & 59.16 & $2.04 \mathrm{E}-60$ & $2.05 \mathrm{E}-50$ & $0.00 \mathrm{E}+00$ & $3.61 \mathrm{E}+06$ & $1.16 \mathrm{E}-18$ & $1.16 \mathrm{E}-08$ \\
\hline 1.5 & 88.73 & $2.04 \mathrm{E}-67$ & $2.05 \mathrm{E}-57$ & $0.00 \mathrm{E}+00$ & $3.61 \mathrm{E}+06$ & $1.16 \mathrm{E}-17$ & $1.16 \mathrm{E}-07$ \\
\hline 2 & 118.13 & $2.04 \mathrm{E}-74$ & $2.05 E-64$ & $0.00 \mathrm{E}+00$ & $3.61 E+06$ & $1.16 \mathrm{E}-16$ & $1.16 \mathrm{E}-06$ \\
\hline 2.5 & 147.89 & $2.04 \mathrm{E}-81$ & $2.05 \mathrm{E}-71$ & $0.00 \mathrm{E}+00$ & $3.61 \mathrm{E}+06$ & $1.16 \mathrm{E}-15$ & $1.16 \mathrm{E}-05$ \\
\hline 3 & 177.47 & $2.04 \mathrm{E}-88$ & $2.05 \mathrm{E}-78$ & $0.00 \mathrm{E}+00$ & $3.61 E+06$ & $1.16 \mathrm{E}-14$ & $1.16 \mathrm{E}-04$ \\
\hline 3.5 & 207.05 & $2.04 \mathrm{E}-95$ & $2.05 E-85$ & $0.00 \mathrm{E}+00$ & $3.61 \mathrm{E}+06$ & $1.16 \mathrm{E}-13$ & $1.16 \mathrm{E}-03$ \\
\hline 4 & 236.62 & $1.00-100$ & $0.00 E+00$ & $0.00 E+00$ & $3.61 \mathrm{E}+06$ & $1.16 \mathrm{E}-12$ & $1.16 \mathrm{E}-02$ \\
\hline 4.5 & 266.2 & $1.00-100$ & $0.00 \mathrm{E}+00$ & $0.00 \mathrm{E}+00$ & $3.61 \mathrm{E}+06$ & $1.15 \mathrm{E}-11$ & $1.15 \mathrm{E}-01$ \\
\hline 5 & 295.78 & $1.00-100$ & $0.00 \mathrm{E}+00$ & $0.00 \mathrm{E}+00$ & $3.61 E+06$ & $1.13 \mathrm{E}-10$ & $1.13 \mathrm{E}+00$ \\
\hline 5.5 & 325.36 & $1.00-100$ & $0.00 \mathrm{E}+00$ & $0.00 \mathrm{E}+00$ & $3.61 E+06$ & $9.66 \mathrm{E}-10$ & $9.69 \mathrm{E}+00$ \\
\hline 6 & 354.94 & $1.00-100$ & $0.00 E+00$ & $0.00 \mathrm{E}+00$ & $3.61 E+06$ & $3.90 \mathrm{E}-09$ & $3.91 \mathrm{E}+01$ \\
\hline 6.5 & 384.51 & $1.00-100$ & $0.00 \mathrm{E}+00$ & $0.00 \mathrm{E}+00$ & $3.61 \mathrm{E}+06$ & $5.61 \mathrm{E}-09$ & $5.63 \mathrm{E}+01$ \\
\hline 7 & 414.09 & $1.00-100$ & $0.00 \mathrm{E}+00$ & $0.00 \mathrm{E}+00$ & $3.61 \mathrm{E}+06$ & $5.87 \mathrm{E}-09$ & $5.89 E+01$ \\
\hline 7.5 & 443.67 & $1.00-100$ & $0.00 \mathrm{E}+00$ & $0.00 \mathrm{E}+00$ & $3.61 \mathrm{E}+06$ & $5.89 \mathrm{E}-09$ & $5.91 E+01$ \\
\hline 8 & 437.25 & $1.00-100$ & $0.00 E+00$ & $0.00 E+00$ & $3.61 \mathrm{E}+06$ & $5.90 \mathrm{E}-09$ & $5.92 \mathrm{E}+01$ \\
\hline 8.5 & 502.83 & $1.00-100$ & $0.00 \mathrm{E}+00$ & $0.00 \mathrm{E}+00$ & $3.61 E+06$ & 5.89E-09 & $5.91 \mathrm{E}+01$ \\
\hline 9 & 532.4 & $1.00-100$ & $0.00 \mathrm{E}+00$ & $0.00 \mathrm{E}+00$ & $3.61 \mathrm{E}+06$ & $5.89 \mathrm{E}-09$ & $5.91 \mathrm{E}+01$ \\
\hline 9.5 & 561.98 & $1.00-100$ & $0.00 \mathrm{E}+00$ & $0.00 \mathrm{E}+00$ & $3.61 \mathrm{E}+06$ & $5.89 \mathrm{E}-09$ & $5.91 E+01$ \\
\hline 10 & 591.56 & $1.00-100$ & $0.00 \mathrm{E}+00$ & $0.00 E+00$ & $3.61 E+06$ & $5.89 \mathrm{E}-09$ & $5.91 \mathrm{E}+01$ \\
\hline 10.5 & 621.14 & $1.00-100$ & $0.00 \mathrm{E}+00$ & $0.00 E+00$ & $3.61 \mathrm{E}+06$ & $5.89 \mathrm{E}-09$ & $5.91 \mathrm{E}+01$ \\
\hline 11 & 650.72 & $1.00-100$ & $0.00 \mathrm{E}+00$ & $0.00 \mathrm{E}+00$ & $3.61 \mathrm{E}+06$ & $5.89 \mathrm{E}-09$ & $5.91 \mathrm{E}+01$ \\
\hline 11.5 & 680.29 & $1.00-100$ & $0.00 \mathrm{E}+00$ & $0.00 \mathrm{E}+00$ & $3.61 \mathrm{E}+06$ & $5.89 \mathrm{E}-09$ & $5.91 \mathrm{E}+01$ \\
\hline 12 & 709.87 & $1.00-100$ & $0.00 \mathrm{E}+00$ & $0.00 \mathrm{E}+00$ & $3.61 \mathrm{E}+06$ & $5.89 \mathrm{E}-09$ & $5.91 \mathrm{E}+01$ \\
\hline 12.5 & 739.45 & $1.00-100$ & $0.00 \mathrm{E}+00$ & $0.00 \mathrm{E}+00$ & $3.61 \mathrm{E}+06$ & $5.89 \mathrm{E}-09$ & $5.91 \mathrm{E}+01$ \\
\hline 13 & 769.03 & $1.00-100$ & $0.00 \mathrm{E}+00$ & $0.00 \mathrm{E}+00$ & $3.61 \mathrm{E}+06$ & 5.89E-09 & $5.91 \mathrm{E}+01$ \\
\hline 13.5 & 798.6 & $1.00-100$ & $0.00 \mathrm{E}+00$ & $0.00 \mathrm{E}+00$ & $3.61 \mathrm{E}+06$ & $5.89 \mathrm{E}-09$ & $5.91 \mathrm{E}+01$ \\
\hline
\end{tabular}


Table A3 (Continuation). Mercury Speciation at pH of 7 and Total Mercury Concentration of 0.002 $\mathrm{mg} / \mathrm{L}$ (Data Used in Figure 4).

\begin{tabular}{|c|c|c|c|c|c|c|c|}
\hline $\mathrm{pE}$ & $\begin{array}{c}\text { Eh } \\
(\mathrm{mV})\end{array}$ & $\begin{array}{c}\text { Conc. (M) } \\
\mathrm{HgCl}_{3}^{-}\end{array}$ & $\begin{array}{l}\text { Percent } \\
\mathrm{HgCl}_{3}{ }^{-}\end{array}$ & $\begin{array}{l}\text { Conc. (M) } \\
\mathrm{HgCl}_{4}^{2-}\end{array}$ & $\begin{array}{l}\text { Percent } \\
\mathrm{HgCl}_{4}^{2-}\end{array}$ & $\begin{array}{c}\text { Conc. (M) } \\
\mathrm{Hg}(\mathrm{aq})\end{array}$ & $\begin{array}{l}\text { Percent } \\
\mathrm{Hg}(\mathrm{aq})\end{array}$ \\
\hline-2 & -200 & $5.87 \mathrm{E}-25$ & $5.89 \mathrm{E}-15$ & $1.74 \mathrm{E}-25$ & $1.75 \mathrm{E}-15$ & $9.97 \mathrm{E}-09$ & $1.00 \mathrm{E}+02$ \\
\hline-1.5 & -88.73 & $5.87 \mathrm{E}-24$ & $5.89 \mathrm{E}-14$ & $1.74 \mathrm{E}-24$ & $1.75 \mathrm{E}-14$ & 9.97E-09 & $1.00 \mathrm{E}+02$ \\
\hline-1 & -59.16 & $5.87 \mathrm{E}-23$ & $5.89 \mathrm{E}-13$ & $1.74 \mathrm{E}-23$ & $1.75 \mathrm{E}-13$ & $9.97 \mathrm{E}-09$ & $1.00 \mathrm{E}+02$ \\
\hline-0.5 & -29.58 & $5.87 \mathrm{E}-22$ & $5.89 \mathrm{E}-12$ & $1.74 \mathrm{E}-22$ & $1.75 \mathrm{E}-12$ & $9.97 \mathrm{E}-09$ & $1.00 \mathrm{E}+02$ \\
\hline 0 & -0.095 & $5.87 \mathrm{E}-21$ & $5.89 \mathrm{E}-11$ & $1.74 \mathrm{E}-21$ & $1.75 \mathrm{E}-11$ & 9.97E-09 & $1.00 \mathrm{E}+02$ \\
\hline 0.5 & 29.58 & $5.87 \mathrm{E}-20$ & $5.89 \mathrm{E}-10$ & $1.74 \mathrm{E}-20$ & $1.75 \mathrm{E}-10$ & $9.97 \mathrm{E}-09$ & $1.00 \mathrm{E}+02$ \\
\hline 1 & 59.16 & $5.87 \mathrm{E}-19$ & $5.89 \mathrm{E}-09$ & $1.74 \mathrm{E}-19$ & $1.75 \mathrm{E}-09$ & 9.97E-09 & $1.00 \mathrm{E}+02$ \\
\hline 1.5 & 88.73 & $5.87 \mathrm{E}-18$ & $5.89 \mathrm{E}-08$ & $1.74 \mathrm{E}-18$ & $1.75 \mathrm{E}-08$ & $9.97 \mathrm{E}-09$ & $1.00 \mathrm{E}+02$ \\
\hline 2 & 118.13 & $5.87 \mathrm{E}-17$ & $5.89 \mathrm{E}-07$ & $1.74 \mathrm{E}-17$ & $1.75 \mathrm{E}-07$ & $9.97 \mathrm{E}-09$ & $1.00 \mathrm{E}+02$ \\
\hline 2.5 & 147.89 & $5.87 \mathrm{E}-16$ & $5.89 \mathrm{E}-06$ & $1.74 \mathrm{E}-16$ & $1.75 \mathrm{E}-06$ & $9.97 \mathrm{E}-09$ & $1.00 \mathrm{E}+02$ \\
\hline 3 & 177.47 & $5.87 \mathrm{E}-15$ & $5.89 \mathrm{E}-05$ & $1.74 \mathrm{E}-15$ & $1.75 \mathrm{E}-05$ & $9.97 \mathrm{E}-09$ & $1.00 \mathrm{E}+02$ \\
\hline 3.5 & 207.05 & $5.87 \mathrm{E}-14$ & $5.89 \mathrm{E}-04$ & $1.74 \mathrm{E}-14$ & $1.75 \mathrm{E}-04$ & $9.97 \mathrm{E}-09$ & $1.00 \mathrm{E}+02$ \\
\hline 4 & 236.62 & $5.87 \mathrm{E}-13$ & $5.89 \mathrm{E}-03$ & $1.74 \mathrm{E}-13$ & $1.75 \mathrm{E}-03$ & $9.97 \mathrm{E}-09$ & $1.00 \mathrm{E}+02$ \\
\hline 4.5 & 266.2 & $5.86 \mathrm{E}-12$ & $5.88 \mathrm{E}-02$ & $1.74 \mathrm{E}-12$ & $1.75 \mathrm{E}-02$ & 9.95E-09 & $9.98 \mathrm{E}+01$ \\
\hline 5 & 295.78 & $5.76 \mathrm{E}-11$ & $5.78 \mathrm{E}-01$ & $1.71 \mathrm{E}-11$ & $1.72 \mathrm{E}-01$ & $9.78 \mathrm{E}-09$ & $9.81 \mathrm{E}+01$ \\
\hline 5.5 & 325.36 & $4.91 \mathrm{E}-10$ & $4.92 \mathrm{E}+00$ & $1.46 \mathrm{E}-10$ & $1.46 \mathrm{E}+00$ & 8.34E-09 & $8.37 \mathrm{E}+01$ \\
\hline 6 & 354.94 & $1.98 \mathrm{E}-09$ & $1.99 \mathrm{E}+01$ & $5.88 \mathrm{E}-10$ & $5.90 E+00$ & 3.37E-09 & $3.38 \mathrm{E}+01$ \\
\hline 6.5 & 384.51 & $2.85 \mathrm{E}-09$ & $2.86 \mathrm{E}+01$ & $8.45 \mathrm{E}-10$ & $8.48 \mathrm{E}+00$ & $4.84 \mathrm{E}-10$ & $4.85 \mathrm{E}+00$ \\
\hline 7 & 414.09 & $2.98 \mathrm{E}-09$ & $2.99 \mathrm{E}+01$ & $8.84 \mathrm{E}-10$ & $8.87 \mathrm{E}+00$ & $5.06 \mathrm{E}-11$ & $5.08 \mathrm{E}-01$ \\
\hline 7.5 & 443.67 & $3.00 \mathrm{E}-09$ & $3.01 E+01$ & $8.88 \mathrm{E}-10$ & $8.91 E+00$ & $5.08 \mathrm{E}-12$ & $5.10 \mathrm{E}-02$ \\
\hline 8 & 437.25 & $3.00 \mathrm{E}-09$ & $3.01 \mathrm{E}+01$ & $8.88 \mathrm{E}-10$ & $8.91 \mathrm{E}+00$ & $5.09 \mathrm{E}-13$ & $5.11 \mathrm{E}-03$ \\
\hline 8.5 & 502.83 & $3.00 \mathrm{E}-09$ & $3.01 \mathrm{E}+01$ & $8.89 \mathrm{E}-10$ & $8.92 E+00$ & $5.08 \mathrm{E}-14$ & $5.10 \mathrm{E}-04$ \\
\hline 9 & 532.4 & $3.00 \mathrm{E}-09$ & $3.01 E+01$ & $8.89 \mathrm{E}-10$ & $8.92 E+00$ & $5.08 \mathrm{E}-15$ & $5.10 \mathrm{E}-05$ \\
\hline 9.5 & 561.98 & $3.00 \mathrm{E}-09$ & $3.01 E+01$ & $8.89 \mathrm{E}-10$ & $8.92 E+00$ & $5.08 \mathrm{E}-16$ & $5.10 \mathrm{E}-06$ \\
\hline 10 & 591.56 & $3.00 \mathrm{E}-09$ & $3.01 E+01$ & $8.89 \mathrm{E}-10$ & $8.92 \mathrm{E}+00$ & $5.08 \mathrm{E}-17$ & $5.10 \mathrm{E}-07$ \\
\hline 10.5 & 621.14 & $3.00 \mathrm{E}-09$ & $3.01 \mathrm{E}+01$ & $8.89 \mathrm{E}-10$ & $8.92 \mathrm{E}+00$ & $5.08 \mathrm{E}-18$ & $5.10 \mathrm{E}-08$ \\
\hline 11 & 650.72 & $3.00 \mathrm{E}-09$ & $3.01 \mathrm{E}+01$ & $8.89 \mathrm{E}-10$ & $8.92 E+00$ & $5.08 \mathrm{E}-19$ & $5.10 \mathrm{E}-09$ \\
\hline 11.5 & 680.29 & $3.00 \mathrm{E}-09$ & $3.01 \mathrm{E}+01$ & $8.89 \mathrm{E}-10$ & $8.92 \mathrm{E}+00$ & $5.08 \mathrm{E}-20$ & $5.10 \mathrm{E}-10$ \\
\hline 12 & 709.87 & $3.00 \mathrm{E}-09$ & $3.01 E+01$ & $8.89 \mathrm{E}-10$ & $8.92 E+00$ & $5.08 \mathrm{E}-21$ & $5.10 \mathrm{E}-11$ \\
\hline 12.5 & 739.45 & $3.00 \mathrm{E}-09$ & $3.01 E+01$ & $8.89 \mathrm{E}-10$ & $8.92 \mathrm{E}+00$ & $5.08 \mathrm{E}-22$ & $5.10 \mathrm{E}-12$ \\
\hline 13 & 769.03 & $3.00 \mathrm{E}-09$ & $3.01 \mathrm{E}+01$ & $8.89 \mathrm{E}-10$ & $8.92 E+00$ & $5.08 \mathrm{E}-23$ & $5.10 \mathrm{E}-13$ \\
\hline 13.5 & 798.6 & $3.00 \mathrm{E}-09$ & $3.01 \mathrm{E}+01$ & $8.89 \mathrm{E}-10$ & $8.92 \mathrm{E}+00$ & $5.08 \mathrm{E}-24$ & $5.10 \mathrm{E}-14$ \\
\hline
\end{tabular}


Table A4. Mercury Speciation at $\mathrm{pH}$ of 7 and Total Mercury Concentration of $0.2 \mathrm{mg} / \mathrm{L}$ (Data Used in Figure 5).

\begin{tabular}{|c|c|c|c|c|c|c|c|c|c|}
\hline $\mathrm{pE}$ & $\begin{array}{c}\text { Eh } \\
(\mathrm{mV})\end{array}$ & $\begin{array}{l}\text { Conc. (M) } \\
\mathrm{Hg}\left(\mathrm{CH}_{3}\right) \mathrm{S}^{-}\end{array}$ & $\begin{array}{c}\text { Percent } \\
\mathrm{Hg}\left(\mathrm{CH}_{3}\right) \mathrm{S}^{-}\end{array}$ & $\begin{array}{l}\text { Conc. (M) } \\
\mathrm{Hg}(\mathrm{HS})_{2}\end{array}$ & $\begin{array}{c}\text { Percent } \\
\mathrm{Hg}(\mathrm{HS})_{3}\end{array}$ & $\begin{array}{l}\text { Conc. (M) } \\
\mathrm{HgCl}_{2}(\mathrm{aq})\end{array}$ & $\begin{array}{c}\text { Percent } \\
\mathrm{HgCl}_{2} \text { (aq) }\end{array}$ & $\begin{array}{l}\text { Conc. (M) } \\
\mathrm{HgCl}_{3}^{-}\end{array}$ & $\begin{array}{l}\text { Percent } \\
\mathrm{HgCl}_{3}^{-}\end{array}$ \\
\hline-2 & -200 & $5.74 \mathrm{E}-17$ & $5.74 \mathrm{E}-09$ & $0.00 \mathrm{E}+00$ & $0.00 \mathrm{E}+00$ & $3.26 \mathrm{E}-23$ & $3.26 \mathrm{E}-15$ & $1.66 \mathrm{E}-23$ & $1.66 \mathrm{E}-15$ \\
\hline-1.5 & -88.73 & $5.74 \mathrm{E}-24$ & $5.74 \mathrm{E}-16$ & $0.00 \mathrm{E}+00$ & $0.00 \mathrm{E}+00$ & $3.26 \mathrm{E}-22$ & $3.26 \mathrm{E}-14$ & $1.66 \mathrm{E}-22$ & $1.66 \mathrm{E}-14$ \\
\hline-1 & -59.16 & $5.74 \mathrm{E}-31$ & $5.74 \mathrm{E}-23$ & $0.00 \mathrm{E}+00$ & $0.00 \mathrm{E}+00$ & $3.26 \mathrm{E}-21$ & $3.26 \mathrm{E}-13$ & $1.66 \mathrm{E}-21$ & $1.66 \mathrm{E}-13$ \\
\hline-0.5 & -29.58 & $5.74 \mathrm{E}-38$ & $5.74 \mathrm{E}-30$ & $0.00 \mathrm{E}+00$ & $0.00 \mathrm{E}+00$ & $3.26 \mathrm{E}-20$ & $3.26 \mathrm{E}-12$ & $1.66 \mathrm{E}-20$ & $1.66 \mathrm{E}-12$ \\
\hline 0 & -0.095 & $5.74 \mathrm{E}-45$ & $5.74 \mathrm{E}-37$ & $0.00 \mathrm{E}+00$ & $0.00 \mathrm{E}+00$ & $3.26 \mathrm{E}-19$ & $3.26 \mathrm{E}-11$ & $1.66 \mathrm{E}-19$ & $1.66 \mathrm{E}-11$ \\
\hline 0.5 & 29.58 & $5.74 \mathrm{E}-52$ & $5.74 \mathrm{E}-44$ & $0.00 \mathrm{E}+00$ & $0.00 \mathrm{E}+00$ & $3.26 \mathrm{E}-18$ & $3.26 \mathrm{E}-10$ & $1.66 \mathrm{E}-18$ & $1.66 \mathrm{E}-10$ \\
\hline 1 & 59.16 & $5.74 \mathrm{E}-59$ & $5.74 \mathrm{E}-51$ & $0.00 \mathrm{E}+00$ & $0.00 \mathrm{E}+00$ & $3.26 \mathrm{E}-17$ & $3.26 \mathrm{E}-09$ & $1.66 \mathrm{E}-17$ & $1.66 \mathrm{E}-09$ \\
\hline 1.5 & 88.73 & $5.74 \mathrm{E}-66$ & $5.74 \mathrm{E}-58$ & $0.00 \mathrm{E}+00$ & $0.00 \mathrm{E}+00$ & $3.26 \mathrm{E}-16$ & $3.26 \mathrm{E}-08$ & $1.66 \mathrm{E}-16$ & $1.66 \mathrm{E}-08$ \\
\hline 2 & 118.13 & $5.74 \mathrm{E}-73$ & $5.74 E-65$ & $0.00 \mathrm{E}+00$ & $0.00 \mathrm{E}+00$ & $3.26 \mathrm{E}-15$ & $3.26 \mathrm{E}-07$ & $1.66 \mathrm{E}-15$ & $1.66 \mathrm{E}-07$ \\
\hline 2.5 & 147.89 & $5.74 \mathrm{E}-80$ & $5.74 \mathrm{E}-72$ & $0.00 \mathrm{E}+00$ & $0.00 E+00$ & $3.26 \mathrm{E}-14$ & $3.26 \mathrm{E}-06$ & $1.66 \mathrm{E}-14$ & $1.66 \mathrm{E}-06$ \\
\hline 3 & 177.47 & $5.74 \mathrm{E}-87$ & $5.74 \mathrm{E}-79$ & $0.00 \mathrm{E}+00$ & $0.00 \mathrm{E}+00$ & $3.26 \mathrm{E}-13$ & $3.26 \mathrm{E}-05$ & $1.66 \mathrm{E}-13$ & $1.66 \mathrm{E}-05$ \\
\hline 3.5 & 207.05 & $5.74 \mathrm{E}-94$ & $5.74 \mathrm{E}-86$ & $0.00 \mathrm{E}+00$ & $0.00 \mathrm{E}+00$ & $3.26 \mathrm{E}-12$ & $3.26 \mathrm{E}-04$ & $1.66 \mathrm{E}-12$ & $1.66 \mathrm{E}-04$ \\
\hline 4 & 236.62 & $1.00-100$ & $0.00 \mathrm{E}+00$ & $0.00 \mathrm{E}+00$ & $0.00 \mathrm{E}+00$ & $3.26 \mathrm{E}-11$ & $3.26 \mathrm{E}-03$ & $1.66 \mathrm{E}-11$ & $1.66 \mathrm{E}-03$ \\
\hline 4.5 & 266.2 & $1.00-100$ & $0.00 \mathrm{E}+00$ & $0.00 \mathrm{E}+00$ & $0.00 E+00$ & $3.26 \mathrm{E}-10$ & $3.26 \mathrm{E}-02$ & $1.66 \mathrm{E}-10$ & $1.66 \mathrm{E}-02$ \\
\hline 5 & 295.78 & $1.00-100$ & $0.00 \mathrm{E}+00$ & $0.00 \mathrm{E}+00$ & $0.00 \mathrm{E}+00$ & $3.26 \mathrm{E}-09$ & $3.26 \mathrm{E}-01$ & $1.66 \mathrm{E}-09$ & $1.66 \mathrm{E}-01$ \\
\hline 5.5 & 325.36 & $1.00-100$ & $0.00 \mathrm{E}+00$ & $0.00 \mathrm{E}+00$ & $0.00 \mathrm{E}+00$ & $3.26 \mathrm{E}-08$ & $3.26 E+00$ & $1.66 \mathrm{E}-08$ & $1.66 \mathrm{E}+00$ \\
\hline 6 & 354.94 & $1.00-100$ & $0.00 \mathrm{E}+00$ & $0.00 \mathrm{E}+00$ & $0.00 \mathrm{E}+00$ & $2.58 \mathrm{E}-07$ & $2.58 \mathrm{E}+01$ & $1.31 \mathrm{E}-07$ & $1.31 \mathrm{E}+01$ \\
\hline 6.5 & 384.51 & $1.00-100$ & $0.00 \mathrm{E}+00$ & $0.00 \mathrm{E}+00$ & $0.00 \mathrm{E}+00$ & $5.63 \mathrm{E}-07$ & $5.63 \mathrm{E}+01$ & $2.86 \mathrm{E}-07$ & $2.86 \mathrm{E}+01$ \\
\hline 7 & 414.09 & $1.00-100$ & $0.00 \mathrm{E}+00$ & $0.00 \mathrm{E}+00$ & $0.00 \mathrm{E}+00$ & $5.88 \mathrm{E}-07$ & $5.88 \mathrm{E}+01$ & $2.99 \mathrm{E}-07$ & $2.99 E+01$ \\
\hline 7.5 & 443.67 & $1.00-100$ & $0.00 \mathrm{E}+00$ & $0.00 \mathrm{E}+00$ & $0.00 \mathrm{E}+00$ & $5.91 \mathrm{E}-07$ & $5.91 E+01$ & $3.01 \mathrm{E}-07$ & $3.01 E+01$ \\
\hline 8 & 437.25 & $1.00-100$ & $0.00 \mathrm{E}+00$ & $0.00 \mathrm{E}+00$ & $0.00 E+00$ & $5.91 \mathrm{E}-07$ & $5.91 E+01$ & $3.01 E-07$ & $3.01 E+01$ \\
\hline 8.5 & 502.83 & $1.00-100$ & $0.00 \mathrm{E}+00$ & $0.00 \mathrm{E}+00$ & $0.00 \mathrm{E}+00$ & $5.91 \mathrm{E}-07$ & $5.91 \mathrm{E}+01$ & $3.01 \mathrm{E}-07$ & $3.01 E+01$ \\
\hline 9 & 532.4 & $1.00-100$ & $0.00 \mathrm{E}+00$ & $0.00 \mathrm{E}+00$ & $0.00 \mathrm{E}+00$ & $5.91 \mathrm{E}-07$ & $5.91 \mathrm{E}+01$ & $3.01 \mathrm{E}-07$ & $3.01 E+01$ \\
\hline 9.5 & 561.98 & $1.00-100$ & $0.00 \mathrm{E}+00$ & $0.00 \mathrm{E}+00$ & $0.00 E+00$ & $5.91 \mathrm{E}-07$ & $5.91 \mathrm{E}+01$ & $3.01 \mathrm{E}-07$ & $3.01 E+01$ \\
\hline 10 & 591.56 & $1.00-100$ & $0.00 \mathrm{E}+00$ & $0.00 \mathrm{E}+00$ & $0.00 \mathrm{E}+00$ & $5.91 \mathrm{E}-07$ & $5.91 \mathrm{E}+01$ & $3.01 \mathrm{E}-07$ & $3.01 E+01$ \\
\hline 10.5 & 621.14 & $1.00-100$ & $0.00 \mathrm{E}+00$ & $0.00 \mathrm{E}+00$ & $0.00 \mathrm{E}+00$ & $5.91 \mathrm{E}-07$ & $5.91 \mathrm{E}+01$ & $3.01 \mathrm{E}-07$ & $3.01 \mathrm{E}+01$ \\
\hline 11 & 650.72 & $1.00-100$ & $0.00 E+00$ & $0.00 \mathrm{E}+00$ & $0.00 E+00$ & $5.91 \mathrm{E}-07$ & $5.91 \mathrm{E}+01$ & $3.01 \mathrm{E}-07$ & $3.01 \mathrm{E}+01$ \\
\hline 11.5 & 680.29 & $1.00-100$ & $0.00 \mathrm{E}+00$ & $0.00 \mathrm{E}+00$ & $0.00 \mathrm{E}+00$ & $5.91 \mathrm{E}-07$ & $5.91 E+01$ & $3.01 \mathrm{E}-07$ & $3.01 E+01$ \\
\hline 12 & 709.87 & $1.00-100$ & $0.00 \mathrm{E}+00$ & $0.00 \mathrm{E}+00$ & $0.00 \mathrm{E}+00$ & $5.91 \mathrm{E}-07$ & $5.91 \mathrm{E}+01$ & $3.01 \mathrm{E}-07$ & $3.01 E+01$ \\
\hline 12.5 & 739.45 & $1.00-100$ & $0.00 \mathrm{E}+00$ & $0.00 \mathrm{E}+00$ & $0.00 \mathrm{E}+00$ & $5.91 \mathrm{E}-07$ & $5.91 E+01$ & $3.01 \mathrm{E}-07$ & $3.01 E+01$ \\
\hline 13 & 769.03 & $1.00-100$ & $0.00 E+00$ & $0.00 \mathrm{E}+00$ & $0.00 E+00$ & 5.91E-07 & $5.91 \mathrm{E}+01$ & $3.01 \mathrm{E}-07$ & $3.01 \mathrm{E}+01$ \\
\hline 13.5 & 798.6 & $1.00-100$ & $0.00 \mathrm{E}+00$ & $0.00 \mathrm{E}+00$ & $0.00 \mathrm{E}+00$ & $5.91 \mathrm{E}-07$ & $5.91 \mathrm{E}+01$ & $3.01 \mathrm{E}-07$ & $3.01 E+01$ \\
\hline
\end{tabular}


Table A4 (Continuation). Mercury Speciation at $\mathrm{pH}$ of 7 and Total Mercury Concentration of $0.2 \mathrm{mg} / \mathrm{L}$ (Data Used in Figure 5).

\begin{tabular}{|c|c|c|c|c|c|c|c|}
\hline $\mathrm{pE}$ & $\begin{array}{c}\text { Eh } \\
(\mathrm{mV})\end{array}$ & $\begin{array}{c}\text { Conc. (M) } \\
\mathrm{HgCl}_{4}^{2-}\end{array}$ & $\begin{array}{l}\text { Percent } \\
\mathrm{HgCl}_{4}^{2-}\end{array}$ & $\begin{array}{c}\text { Conc. (M) } \\
\mathrm{Hg}(\mathrm{aq})\end{array}$ & $\begin{array}{l}\text { Percent } \\
\mathrm{Hg}(\mathrm{aq})\end{array}$ & $\begin{array}{c}\text { Conc. (M) } \\
\mathrm{Hg}(\mathrm{s})\end{array}$ & $\begin{array}{l}\text { Percent } \\
\mathrm{Hg}(\mathrm{s})\end{array}$ \\
\hline-2 & -200 & $4.91 \mathrm{E}-24$ & $4.91 \mathrm{E}-16$ & $2.81 \mathrm{E}-07$ & $2.81 E+01$ & $3.59 \mathrm{E}-07$ & $7.18 \mathrm{E}+01$ \\
\hline-1.5 & -88.73 & $4.91 \mathrm{E}-23$ & $4.91 \mathrm{E}-15$ & $2.81 \mathrm{E}-07$ & $2.81 E+01$ & $3.59 \mathrm{E}-07$ & $7.18 \mathrm{E}+01$ \\
\hline-1 & -59.16 & $4.91 \mathrm{E}-22$ & $4.91 \mathrm{E}-14$ & $2.81 \mathrm{E}-07$ & $2.81 E+01$ & $3.59 \mathrm{E}-07$ & $7.18 \mathrm{E}+01$ \\
\hline-0.5 & -29.58 & $4.91 \mathrm{E}-21$ & $4.91 \mathrm{E}-13$ & $2.81 \mathrm{E}-07$ & $2.81 E+01$ & $3.59 \mathrm{E}-07$ & $7.18 \mathrm{E}+01$ \\
\hline 0 & -0.095 & $4.91 \mathrm{E}-20$ & $4.91 \mathrm{E}-12$ & $2.81 \mathrm{E}-07$ & $2.81 \mathrm{E}+01$ & $3.59 \mathrm{E}-07$ & $7.18 \mathrm{E}+01$ \\
\hline 0.5 & 29.58 & $4.91 \mathrm{E}-19$ & $4.91 \mathrm{E}-11$ & $2.81 \mathrm{E}-07$ & $2.81 \mathrm{E}+01$ & $3.59 \mathrm{E}-07$ & $7.18 \mathrm{E}+01$ \\
\hline 1 & 59.16 & $4.91 \mathrm{E}-18$ & $4.91 \mathrm{E}-10$ & 2.81E-07 & $2.81 \mathrm{E}+01$ & 3.59E-07 & $7.18 E+01$ \\
\hline 1.5 & 88.73 & $4.91 \mathrm{E}-17$ & $4.91 \mathrm{E}-09$ & $2.81 \mathrm{E}-07$ & $2.81 E+01$ & $3.59 \mathrm{E}-07$ & $7.18 \mathrm{E}+01$ \\
\hline 2 & 118.13 & $4.91 \mathrm{E}-16$ & $4.91 \mathrm{E}-08$ & $2.81 \mathrm{E}-07$ & $2.81 E+01$ & $3.59 \mathrm{E}-07$ & $7.18 \mathrm{E}+01$ \\
\hline 2.5 & 147.89 & $4.91 \mathrm{E}-15$ & $4.91 \mathrm{E}-07$ & $2.81 E-07$ & $2.81 \mathrm{E}+01$ & $3.59 \mathrm{E}-07$ & $7.18 \mathrm{E}+01$ \\
\hline 3 & 177.47 & $4.91 \mathrm{E}-14$ & 4.91E-06 & 2.81E-07 & $2.81 \mathrm{E}+01$ & $3.59 \mathrm{E}-07$ & $7.18 \mathrm{E}+01$ \\
\hline 3.5 & 207.05 & $4.91 \mathrm{E}-13$ & $4.91 \mathrm{E}-05$ & $2.81 \mathrm{E}-07$ & $2.81 E+01$ & $3.59 \mathrm{E}-07$ & $7.18 E+01$ \\
\hline 4 & 236.62 & $4.91 \mathrm{E}-12$ & $4.91 \mathrm{E}-04$ & $2.81 \mathrm{E}-07$ & $2.81 \mathrm{E}+01$ & $3.59 \mathrm{E}-07$ & $7.18 \mathrm{E}+01$ \\
\hline 4.5 & 266.2 & $4.91 \mathrm{E}-11$ & $4.91 \mathrm{E}-03$ & $2.81 \mathrm{E}-07$ & $2.81 \mathrm{E}+01$ & $3.59 \mathrm{E}-07$ & $7.18 E+01$ \\
\hline 5 & 295.78 & $4.91 \mathrm{E}-10$ & $4.91 \mathrm{E}-02$ & $2.81 \mathrm{E}-07$ & $2.81 \mathrm{E}+01$ & $3.57 \mathrm{E}-07$ & $7.14 \mathrm{E}+01$ \\
\hline 5.5 & 325.36 & 4.91E-09 & 4.91E-01 & $2.81 \mathrm{E}-07$ & $2.81 E+01$ & 3.32E-07 & $6.64 \mathrm{E}+01$ \\
\hline 6 & 354.94 & $3.89 \mathrm{E}-08$ & $3.89 \mathrm{E}+00$ & $2.23 \mathrm{E}-07$ & $2.23 E+01$ & $1.70 \mathrm{E}-07$ & $3.40 \mathrm{E}+01$ \\
\hline 6.5 & 384.51 & $8.48 \mathrm{E}-08$ & $8.48 E+00$ & $4.86 \mathrm{E}-08$ & $4.86 \mathrm{E}+00$ & $0.00 \mathrm{E}+00$ & $0.00 \mathrm{E}+00$ \\
\hline 7 & 414.09 & $8.86 \mathrm{E}-08$ & $8.86 \mathrm{E}+00$ & $5.08 \mathrm{E}-09$ & $5.08 \mathrm{E}-01$ & $0.00 \mathrm{E}+00$ & $0.00 \mathrm{E}+00$ \\
\hline 7.5 & 443.67 & $8.90 \mathrm{E}-08$ & $8.90 \mathrm{E}+00$ & $5.10 \mathrm{E}-10$ & $5.10 \mathrm{E}-02$ & $0.00 \mathrm{E}+00$ & $0.00 E+00$ \\
\hline 8 & 437.25 & 8.91E-08 & $8.91 E+00$ & $5.10 \mathrm{E}-11$ & $5.10 \mathrm{E}-03$ & $0.00 \mathrm{E}+00$ & $0.00 \mathrm{E}+00$ \\
\hline 8.5 & 502.83 & $8.91 \mathrm{E}-08$ & $8.91 \mathrm{E}+00$ & $5.10 \mathrm{E}-12$ & $5.10 \mathrm{E}-04$ & $0.00 \mathrm{E}+00$ & $0.00 \mathrm{E}+00$ \\
\hline 9 & 532.4 & $8.91 \mathrm{E}-08$ & $8.91 E+00$ & $5.10 \mathrm{E}-13$ & $5.10 \mathrm{E}-05$ & $0.00 \mathrm{E}+00$ & $0.00 \mathrm{E}+00$ \\
\hline 9.5 & 561.98 & $8.91 \mathrm{E}-08$ & $8.91 E+00$ & $5.10 \mathrm{E}-14$ & $5.10 \mathrm{E}-06$ & $0.00 \mathrm{E}+00$ & $0.00 \mathrm{E}+00$ \\
\hline 10 & 591.56 & $8.91 \mathrm{E}-08$ & $8.91 E+00$ & $5.10 \mathrm{E}-15$ & $5.10 \mathrm{E}-07$ & $0.00 \mathrm{E}+00$ & $0.00 \mathrm{E}+00$ \\
\hline 10.5 & 621.14 & $8.91 \mathrm{E}-08$ & $8.91 \mathrm{E}+00$ & $5.10 \mathrm{E}-16$ & $5.10 \mathrm{E}-08$ & $0.00 \mathrm{E}+00$ & $0.00 \mathrm{E}+00$ \\
\hline 11 & 650.72 & $8.91 E-08$ & $8.91 E+00$ & $5.10 \mathrm{E}-17$ & $5.10 \mathrm{E}-09$ & $0.00 \mathrm{E}+00$ & $0.00 \mathrm{E}+00$ \\
\hline 11.5 & 680.29 & 8.91E-08 & $8.91 E+00$ & $5.10 \mathrm{E}-18$ & $5.10 \mathrm{E}-10$ & $0.00 \mathrm{E}+00$ & $0.00 \mathrm{E}+00$ \\
\hline 12 & 709.87 & $8.91 \mathrm{E}-08$ & $8.91 E+00$ & $5.10 \mathrm{E}-19$ & $5.10 \mathrm{E}-11$ & $0.00 \mathrm{E}+00$ & $0.00 \mathrm{E}+00$ \\
\hline 12.5 & 739.45 & 8.91E-08 & $8.91 E+00$ & $5.10 \mathrm{E}-20$ & $5.10 \mathrm{E}-12$ & $0.00 \mathrm{E}+00$ & $0.00 \mathrm{E}+00$ \\
\hline 13 & 769.03 & 8.91E-08 & $8.91 E+00$ & $5.10 \mathrm{E}-21$ & $5.10 \mathrm{E}-13$ & $0.00 \mathrm{E}+00$ & $0.00 \mathrm{E}+00$ \\
\hline 13.5 & 798.6 & $8.91 \mathrm{E}-08$ & $8.91 E+00$ & $5.10 \mathrm{E}-22$ & $5.10 \mathrm{E}-14$ & $0.00 E+00$ & $0.00 \mathrm{E}+00$ \\
\hline
\end{tabular}




\section{Distribution}

\section{Westinghouse Savannah River Company, Aiken SC}

B. T. Butcher, Bld. 773-43A, Rm. 216.

C. M. Cole, Bld. 773-2B, Rm. 3162.

J. Cardoso-Neto, Bld. 730-2B, Rm. 3128.

K. R. Conner, Bld. 730-2B, Rm. 1099.

C. P. Coffey, Bld. 773-A, Rm. E-114.

J. R. Cook, Bld. 773-43A, Rm. 209.

R. R. Craig, Bld. 730-2B, Rm. 3000.

M. E. Denham, Jr., Bld 773-42A, Rm. 218.

D. I. Kaplan, Bld. 773-43A, Rm. 215.

A. S. Knox, Bld. 737A, Rm. 121.

W. C. Miles, Jr., Bld 730-2B, Rm. 3159.

D. C. Noffsinger, Bld 730-2B, Rm. 3136 .

W. W. Pidcoe, Bld. 730-2B, Rm. 1069.

S. M. Serkiz, Bld. 773A, Rm. B121.

W. L. Specht, 773-42A, Rm. 239.

STI, 4 copies, 703-43A

WPT File, 773-43A

\section{Clemson University, Clemson, South Carolina 29634-0919}

J. Myers, Environmental Engineering \& Science 